\title{
Development of a life-cycle impact assessment methodology linked to the Planetary Boundaries framework
}

Ryberg, Morten W.; Owsianiak, Mikolaj; Richardson, Katherine; Hauschild, Michael Zwicky

Published in:

Ecological Indicators

Link to article, DOI:

10.1016/j.ecolind.2017.12.065

Publication date:

2018

Document Version

Peer reviewed version

Link back to DTU Orbit

Citation (APA):

Ryberg, M. W., Owsianiak, M., Richardson, K., \& Hauschild, M. Z. (2018). Development of a life-cycle impact assessment methodology linked to the Planetary Boundaries framework. Ecological Indicators, 88, 250-262. https://doi.org/10.1016/j.ecolind.2017.12.065

\section{General rights}

Copyright and moral rights for the publications made accessible in the public portal are retained by the authors and/or other copyright owners and it is a condition of accessing publications that users recognise and abide by the legal requirements associated with these rights.

- Users may download and print one copy of any publication from the public portal for the purpose of private study or research.

- You may not further distribute the material or use it for any profit-making activity or commercial gain

- You may freely distribute the URL identifying the publication in the public portal 


\title{
Development of a life-cycle impact assessment methodology linked to the Planetary Boundaries framework
}

\author{
Morten W Ryberg ${ }^{1 \star}$, Mikołaj Owsianiak ${ }^{1}$, Katherine Richardson ${ }^{2}$ and Michael Z Hauschild ${ }^{1}$ \\ ${ }^{1}$ Division for Quantitative Sustainability Assessment, Department of Management Engineering, Technical \\ University of Denmark, Bygningstorvet, Building 116b, 2800 Kgs. Lyngby, Denmark \\ ${ }^{2}$ Center for Macroecology, Evolution and Climate, Danish Natural History Museum, University of Copenhagen, \\ Universitetsparken 15, Building 3, 2100 Copenhagen, Denmark
}

*Corresponding author: $\underline{\text { moryb@dtu.dk }}$

\begin{abstract}
To enable quantifying environmental performance of products and technologies in relation to Planetary Boundaries, there is a need for life-cycle impact assessment (LCIA) methods which allow for expressing indicators of environmental impact in metrics corresponding to those of the control variables in the Planetary Boundaries framework. In this study, we present such a methodology, referred to as PB-LCIA. Characterization factors for direct use in the LCIA phase of a life cycle assessment, or other life-cycle based assessment, were developed for a total of 85 elementary flows recognized as dominant contributors to transgressing specific Planetary Boundaries. Exception was made for "biosphere integrity" and "introduction of novel entities" where a Planetary Boundary is yet to be defined for the latter and characterization models are considered immature for the former. The PB-LCIA can be used to quantify the share of the "safe operating space" that human activities occupy, as was illustrated by calculating indicator scores for about 10,600 products, technologies and services exemplifying several sectors, including materials, energy, transport, and processing. The PB-LCIA can be used by companies interested in gauging their activities against the Planetary Boundaries to support decisions that help to reduce the risk of human activities moving the Earth System out of the Holocene state.
\end{abstract}

Keywords: Life-cycle assessment; Sustainability; Planetary Boundaries; Life-cycle impact assessment 
Ryberg MW, Owsianiak M, Richardson K, Hauschild MZ (2018) Development of a life-cycle impact assessment methodology linked to the Planetary Boundaries framework. Ecol Indic 88:250-262. doi:

10.1016/j.ecolind.2017.12.065

\section{Introduction}

It has become evident that depletion of Earth's natural resources and services, through human activities, can lead to undesirable conditions on Earth (Daily and Ehrlich 1992; Vitousek 1997). In an attempt to reduce the risk of human activities inadvertently leading to a change in Earth System state towards conditions less conducive to humanity, the Planetary Boundaries (PB) framework (Rockström et al. 2009a; Steffen et al. 2015) identified nine key Earth System processes and defined quantitative 'Planetary boundaries' which delimit a "safe operating space" for humanity to act within. The metric of the PB and the state of the Earth System process is expressed by a control variable defined as either an environmental state or flow rate (e.g. stratospheric ozone concentration measured in Dobson units and anthropogenic nitrogen fixation in $\operatorname{Tg} \mathrm{N}$ per year). Although none of the PBs, in principle, should be transgressed in order to minimize the risk of human activities pushing the Earth System out of its Holocene-like state, anthropogenic pressures have already led to exceedance or near exceedance of several PBs (Steffen et al. 2015). The PB-framework has been adopted by different societal actors such as governmental organizations and industries who have an interest in expressing sustainability in relation to the PBs (Galaz et al. 2012; Stockholm Resilience Centre 2015; Sim et al. 2016; Bjørn et al. 2016; Clift et al. 2017). Despite this interest, however, consistent and operational methods for quantifying human activities (including the creation of products and technologies) in relation to the PBs are lacking.

\subsection{Planetary Boundaries and life-cycle assessment}

Life-cycle assessment (LCA) is a decision support tool (ISO 2006a; ISO 2006b; EC-JRC 2010a) for quantifying impacts of human activities on environment, resources, and humans. LCA involves construction of a life-cycle inventory (LCI) comprising all elementary flows (i.e. emissions and resource uses) arising throughout the lifecycle of the assessed activity. The elementary flows in the LCl are, in the life-cycle impact assessment (LCIA) phase, characterized into potential impacts by multiplication with characterization factors (CFs). LCA has been identified as a useful tool for quantifying human activities relative to the safe operating space because LCA is based on the holistic principles of assessing the full life-cycle and including all relevant environmental impacts (Bjørn et al. 2015; Ryberg et al. 2016).

Approaches for including the PB-framework in LCA have already been put forward. This was initially seen through development of weighting factors for existing impact categories based on the distance between the PBs and their control variable value (Tuomisto et al. 2012) and as development of normalization references, based on carrying capacities and matched with existing impact categories in LCA (Bjørn and Hauschild 2015; 
Ryberg MW, Owsianiak M, Richardson K, Hauschild MZ (2018) Development of a life-cycle impact assessment methodology linked to the Planetary Boundaries framework. Ecol Indic 88:250-262. doi:

10.1016/j.ecolind.2017.12.065

Sandin et al. 2015). The conversion of the metrics in the PB-framework to existing impact categories in LCA is not straightforward as there is general misalignment within the impact pathways (cause-effect chain mechanisms leading from pollutant emission or resource use to impacts) between the position of conventional LCA indicators and control variables of the PB-framework (Ryberg et al. 2016; Laurent and Owsianiak 2017). In addition, there is a fundamental difference between conventional LCA indicators and control variables of the PB-framework with regard to the area of protection (resources, ecosystems and human health in LCA, versus Holocene state of the Earth System in the PB-framework) (Ryberg et al. 2016). These important differences pose a challenge with respect to the communication of results to decision makers who may not be familiar with conventional LCA indicators. Communication to decision makers in industries and governments could potentially be eased by expressing impacts in metrics of the PBs which are already known to decision makers. Doka $(2015 ; 2016)$ presented an LCIA method where impacts of activities were related to a global annual per capita PB allowance, generally expressed in the metrics of the PBs. However, the method's indicators are preallocated into an annual equal per capita personal budget which limits the method's applicability to assessments regarding the share of a personal budget occupied by an activity. Thus, the method is suited for consumer-citizen guidance in terms of developing a sustainable lifestyle but is not suited for assessments focusing on how production oriented activities impact the PBs.

Therefore, methods that allow for expressing impacts in the metrics of the PBs and which can be scaled to the scale of the assessed activity, incl. both consumption and production oriented activities, are still required. Having, such method could also aid quantifying and evaluating progress with relation to the $12^{\text {th }}$ sustainable development goal on ensuring sustainable consumption and production patterns (UN 2015). As a first step towards the creation of such method, Ryberg et al. (2016) identified six key challenges for development and implementation of an LCIA that could fully express impact scores in the metrics of the Planetary Boundaries (referred to as PB-LCIA). The identified challenges were:

1. Introduction of a new area of protection: The Holocene state of the Earth System;

2. Calculation of characterization factors for the Earth System processes' control variables for use in Life-Cycle Impact Assessment

3. Identifying and dealing with Earth System processes where the impacts overlap;

4. Facilitating spatial differentiation of control variables at sub-global level;

5. Applying the precautionary principle instead of best-estimates for defining the safe operating space; 
Ryberg MW, Owsianiak M, Richardson K, Hauschild MZ (2018) Development of a life-cycle impact assessment methodology linked to the Planetary Boundaries framework. Ecol Indic 88:250-262. doi:

10.1016/j.ecolind.2017.12.065

6. Inclusion of environmental constraints in Life-Cycle Assessment and how to assign shares of the 'safe operating space' in an operational way for sustainability assessments (Ryberg et al. 2016).

In this study, we address challenge 2, 3, and 4 i.e. the quantification and expression of impact scores for human activities in metrics consistent with the PB control variables. Challenge 2 is addressed through the development of CFs. Challenges 3 and 4 are part of the CF development and are described for the relevant PBs where overlaps are identified (i.e. "change in biosphere integrity", "ocean acidification", and "flow of phosphorus from freshwater to oceans") or are spatially differentiated (i.e. "freshwater use", "land-system change", and "atmospheric aerosol loading"). A discussion regarding how challenges 3 and 4 are resolved and the resulting implications are provided in Section 4.2.

Challenges related to interpretation of results using a PB-LCIA and assigning shares of the safe operating space (challenge 1,5, and 6), and the requirements for applying the LCIA methodology are described and discussed in Section 4.3. These are, however, not fully explored in this study where the main focus is on the technical challenges of developing CFs which can be used in LCAs, thus establishing the groundwork for applying a PBLCIA methodology. To what degree the PB-LCIA yields similar or different conclusions in comparison with conventional LCIA methodology (ILCD 2011; EC-JRC 2011; Hauschild et al. 2013) is evaluated by calculating impact scores for 10,687 unit processes in the life cycle database ecoinvent which is the most established and comprehensive database of unit processes for LCA. The overall outcome of this study is a PB-LCIA methodology that can be used for assessing impacts of human activities relative to the PBs.

\section{Methods}

\subsection{Current characterization modelling practice}

The current LCIA framework is designed to estimate time integrated exposure [ $\gamma$; mass.time] from a pulse emission of elementary flow [ $\Delta$ m; mass] superimposed on a background level (Heijungs 1995) (Eq. 1).

$$
\gamma=\int_{0}^{T}\left(e^{t \mathbf{A}} \cdot \Delta \mathbf{m}\right) d t
$$

Eq. 1 
Ryberg MW, Owsianiak M, Richardson K, Hauschild MZ (2018) Development of a life-cycle impact assessment methodology linked to the Planetary Boundaries framework. Ecol Indic 88:250-262. doi:

10.1016/j.ecolind.2017.12.065

Where $\mathrm{t}$ is time after emission, $\mathrm{T}$ is time duration over which exposure is considered, and $\mathbf{A}$ is a matrix of coefficients expressing a substance's fate in the environment and exposure of humans and ecosystems. T can either be finite (e.g. $100 \mathrm{yrs}$ as used in the GWP100) or infinite $(T \rightarrow \infty)$ to capture full exposure. The analytical solution to Eq. 1 for $T \rightarrow \infty$ and with negative coefficients in $\mathbf{A}$, i.e. inputs are removed and not generated in the environment, is given in Eq. 2. This gives the conventional framework for characterization modeling in LCA where $\boldsymbol{\gamma}$ expresses the time integrated exposure from the emitted elementary flow. $\boldsymbol{\gamma}$ can be multiplied with an effect factor to express the potential impacts on humans or ecosystems from exposure.

$$
\gamma=-\mathbf{A}^{-1} \cdot \Delta \mathbf{m}
$$

\subsection{Proposed framework for characterization modeling in PB-LCIA}

Control variables in the PB-framework are expressed as environmental states or environmental flow rates where emissions and resource uses from human activities should not lead to exceedance of the PBs. Indeed single occurring pulse emissions do not generally lead to exceedance of PBs. On the other hand, long-term exceedance of PBs can be caused by human activities putting continuous pressure on the environment and this, over time, erodes resilience (Goodland 1995; Scheffer et al. 2001). An LCA intended for relating impact scores to the PBs should include this aspect and, therefore, express impact scores as changes in environmental states or flow rates as a result of continuous pressures (i.e. continuous emission and resource uses).

Because environmental impacts in conventional LCIA are integrated over time and do not relate to a specific point in time, these can only be used for comparative purposes (Heijungs 1995) and not for expressing changes in environmental states or flow rates. An exception is Global Temperature change Potential from a pulse emission (GTP ) (Shine et al. 2005; Levasseur et al. 2016) which express change in surface temperature at a point time as a result of a pulse GHG emission. The magnitude of the GTP indicator is, however, highly sensitive to the specific time point and the indicator will approach zero after sufficiently long time due to removal of the GHG from the atmosphere. Generally, time-integrated impacts are not suitable for expressing impacts in metrics of the control variables in the PB-framework. Instead, to express impact scores as environmental states or flow rates, either at the time of equilibrium (steady state) or other points in time, the presented PB-LCIA method requires that the $\mathrm{LCl}$ provides flows as constant inputs [mass time ${ }^{-1}$ ] instead of pulses [mass]. To accommodate for this, the functional unit (FU) in the LCA, on which the assessment is based, must be defined with a continuous constant time duration, i.e. as annual fulfilment of the function in the FU in 
Ryberg MW, Owsianiak M, Richardson K, Hauschild MZ (2018) Development of a life-cycle impact assessment methodology linked to the Planetary Boundaries framework. Ecol Indic 88:250-262. doi:

10.1016/j.ecolind.2017.12.065

order for the $\mathrm{LCl}$ to express the elementary flows that will occur annually in order to continuously fulfil the FU. The definition of the FU and the specifics surrounding it are further discussed in Section 4.1.2., where examples of how to define the FU in accordance with the new approach are presented. Mathematically, this means that instead of an emission pulse ( $\Delta \mathbf{m}$ in Eq. 2 ), the input for the characterization model is a constant annual flow [S; mass $\left.\mathrm{yr}^{-1}\right]$. Thus, the framework for the characterization modelling in the PB-LCIA follows a first order differential equation which can be solved for steady state (Eq. 3 ) to express the steady state mass ( $\mathbf{m}_{s s}$ ) in the environment from a constant annual input or mass at a specific point in time, where $\dot{\mathbf{m}}$ is a vector of differential quotients $\mathrm{dm}(\mathrm{t}) / \mathrm{dt}$ expressing change of mass with time.

$$
\dot{\mathbf{m}}=-\mathbf{A} \cdot \mathbf{m}(t)+\mathbf{S} \Rightarrow \lim _{t \rightarrow \infty} \dot{\mathbf{m}}=0=-\mathbf{A} \cdot \mathbf{m}(t)+\mathbf{S} \Rightarrow \mathbf{m}_{\mathrm{ss}}=\mathbf{A}^{-1} \cdot \mathbf{S}
$$

\subsection{Characterization models}

The most mature PBs defined in Steffen et al. (2015) were used as a basis for the PB-LCIA and CFs were developed for all PBs except "biosphere integrity" and the "introduction of novel entities" because a PB is yet to be defined for the latter and characterization models are considered immature for the former (Ryberg et al. 2016). Models used for developing CFs draws on existing research and experiences within the field of life-cycle impact assessment and environmental modelling in general. Models were selected based on the following requirements: Models should previously have been used in research (preferable for LCIA or other impact assessment purposes), be evaluated by peer-review, and be documented with detailed description of modelled mechanism and equations. Moreover, the complexity of the models should be consistent with the spatial and temporal scope of the control variable, e.g. a highly spatially differentiated model will not give better results than a non-spatially differentiated model if the indicator is defined at the global level. A general principle for the PB-LCIA method was to use the average approach for derivation of CFs (Huijbregts et al. 2011). The average approach is in line with the principles of the PB-framework, i.e., the adoption of a long-term perspective and giving equal importance to all elementary flows regardless of when they occur as the CFs express the average change in distance between current and preferred environmental state per unit change in elementary flow. For the control variables: "ocean acidification", "stratospheric ozone depletion" and "land-system change", increased values indicate an improved state and, correspondingly, a reduction leads to a worsening. For these 
Ryberg MW, Owsianiak M, Richardson K, Hauschild MZ (2018) Development of a life-cycle impact assessment methodology linked to the Planetary Boundaries framework. Ecol Indic 88:250-262. doi:

10.1016/j.ecolind.2017.12.065

impact categories, the characterization model was developed to follow general LCA conventions where increased impact scores are considered negative and decreased scores considered positive. How impact scores are converted to metrics directly comparable to the control variables is presented under the description of these impact categories.

The general characterization framework was based on models requiring constant inputs, which are provided from the $\mathrm{LCl}$ that expresses the elementary flows occurring annually in order to continuously fulfil the FU. However, there are specific cases of emissions and resource uses that in practice occur only once. This can, nevertheless, be problematic as they can lead to the exceedance of the Earth System's recovery time and, thus potential exceedance of PBs, due to a long residence time in the environment. This can be exemplified with the example of the removal and transformation of natural forest land to agricultural land. In this case, the carbon stored in the soil and vegetation will be released once, i.e., during the transformation. Nevertheless, this single pulse emission of carbon as $\mathrm{CO}_{2}$ may be problematic with respect to climate change due to the long atmospheric residence time of $\mathrm{CO}_{2}$. In this case, specific CFs for emissions of $\mathrm{CO}_{2}$ from land-transformation were estimated where the unit was expressed as "per kg" instead of "per kg per year" to indicate that this is a single occurring pulse emission. This special approach does not affect the ability to compare impacts from continuous constant emissions and pulse emissions as the indicator metric remains the same. CFs were calculated for each of the PB-LCIA impact categories listed in Table 1 using the framework and approaches described above. A brief method description for each impact category is given in this section while specific details are provided in Supporting Info. The governing equations used for characterizing the impact of human activities relative to the Planetary Boundary are presented in Table 1.

\subsubsection{Climate change}

Climate change affects the climate system which results not only in changes in physical conditions (temperature, rainfall, storm activity, sea level, etc.) on Earth but also the biosphere (Rockström et al. 2009a; Steffen et al. 2015). The climate change PB is described by two different control variables, i.e., energy imbalance at top-of-atmosphere expressed by radiative forcing $\left[\mathrm{RF} ; \mathrm{Wm}^{-2}\right]$ and atmospheric $\mathrm{CO}_{2}$ concentration [ppm $\mathrm{CO}_{2}$ ] (Rockström et al. 2009a; Steffen et al. 2015). The control variable for energy imbalance at top-ofatmosphere takes into account all greenhouse gases (GHGs), aerosols, and other factors that affect radiative forcing and is considered more stringent than the boundary for atmospheric $\mathrm{CO}_{2}$ concentration (Steffen et al. 2015). The boundary for atmospheric $\mathrm{CO}_{2}$ concentration only includes $\mathrm{CO}_{2}$ and $\mathrm{CO}_{2}$-precursors and is chosen 
Ryberg MW, Owsianiak M, Richardson K, Hauschild MZ (2018) Development of a life-cycle impact assessment methodology linked to the Planetary Boundaries framework. Ecol Indic 88:250-262. doi:

10.1016/j.ecolind.2017.12.065

because of the large anthropogenic $\mathrm{CO}_{2}$ emissions (Steffen et al. 2015) and because it is a proxy for radiative forcing from all GHGs because the current cooling effect from aerosols approximately counteracts the warming effect of non- $\mathrm{CO}_{2}$ GHGs (Rockström et al. 2009a).

\section{Energy imbalance at top-of-atmosphere}

CFs for energy imbalance at top-of-atmosphere express change in RF per unit change in continuous GHG emissions. The change in RF as a result of a change in GHG emissions was based on the absolute global temperature change potential (AGTP) for a continuous emission (Shine et al. 2005) divided by the equilibrium climate sensitivity parameter which links radiative forcing and temperature (Myhre et al. 2013). AGTP was not valid for $\mathrm{CO}_{2}$ due to its long life time and complex response function (Shine et al. 2005). Therefore, the CF for $\mathrm{CO}_{2}$ was estimated based on the average change in $\mathrm{RF}$ per unit change in $\mathrm{CO}_{2}$ concentration and average change in $\mathrm{CO}_{2}$ concentration per unit change in annual $\mathrm{CO}_{2}$ emissions. The latter was calculated based on an assessment of the RCP2.6 scenario (Meinshausen et al. 2011; van Vuuren et al. 2011) and the former was based on how a change in $\mathrm{CO}_{2}$ concentration affects RF (Myhre et al. 1998; Myhre et al. 2013). For the land transformation, specific CFs, the average change in $\mathrm{CO}_{2}$ concentration was estimated as average change in atmospheric $\mathrm{CO}_{2}$ concentration per kg of the total tolerable mass of $\mathrm{CO}_{2}$ emitted between 2000 and 2300 based on the RCP2.6 scenario in Meinshausen et al. (2011) and averaged over the $300 \mathrm{yr}$ time horizon to express the pulse emission as an average emission flux over $300 \mathrm{yrs}$. The $300 \mathrm{yr}$ time horizon was selected because the atmospheric $\mathrm{CO}_{2}$ concentration was found to start stabilizing and to approach steady state after this period (see Figure S1).

\section{Atmospheric $\mathrm{CO}_{2}$ concentration}

CFs for atmospheric $\mathrm{CO}_{2}$ concentration express the average change in atmospheric $\mathrm{CO}_{2}$ concentration from a change in continuous annual emissions of $\mathrm{CO}_{2}$ or $\mathrm{CO}_{2}$-precursors and was estimated based on an assessment of the RCP2.6 scenario (Meinshausen et al. 2011). $\mathrm{CO}_{2}$-precursors which are converted to $\mathrm{CO}_{2}$ after reaching the troposphere were included via the mass of the emitted substance which is converted to mass of $\mathrm{CO}_{2}$ in the atmosphere, i.e. 1.57, 2.75 (Gillenwater et al. 2006), 3, 2, and 1 (Wenzel and Hauschild 1998) for $\mathrm{CO}, \mathrm{CH}_{4}$, NMVOC as hydrocarbons, NMVOC as partly oxidized hydrocarbons, and NMVOC as partly chlorinated hydrocarbons, respectively. Again, emissions that occur as one off pulse emissions, such as land transformation, were treated as special cases by estimating land transformation specific CFs where the unit was expressed in "per kg" instead of "per kg per year". 
Ryberg MW, Owsianiak M, Richardson K, Hauschild MZ (2018) Development of a life-cycle impact assessment methodology linked to the Planetary Boundaries framework. Ecol Indic 88:250-262. doi:

10.1016/j.ecolind.2017.12.065

\subsubsection{Stratospheric ozone depletion}

Stratospheric ozone depletion is problematic as the ozone layer protects humans and other organisms by absorbing harmful ultraviolet-B (UV-B) radiation from the sun (Fahey and Hegglin 2011). Stratospheric ozone is removed by reactions with chlorine and bromine which are present in the stratosphere due to emissions of long-lived ozone depleting substances (ODS) (Fahey and Hegglin 2011). CFs for stratospheric ozone depletion [Dobson units: DU $\mathrm{yr} \mathrm{kg}^{-1}$ ] were calculated via a number of steps starting from the continuous emission of ODS $\left[\mathrm{kg} \mathrm{yr}^{-1}\right]$, over a change in tropospheric chlorine loading through a change in equivalent stratospheric chlorine level ending with the change in stratospheric ozone concentration [DU]. To comply with general LCA conventions where increased impact scores are considered negative, impact scores calculated with the CF express the absolute change in stratospheric ozone concentration as a result of the assessed activity (|DU|). Thus, an increasing distance indicates a lowering of stratospheric ozone concentration. The impact scores can be converted to an absolute stratospheric ozone concentration value by deducting the absolute difference from the pre-industrial stratospheric ozone concentration level to get the stratospheric ozone concentration in response to the assessed activity.

\subsubsection{Ocean acidification}

Ocean acidification occurs through accumulation of carbonic acid in the oceans created as the ${ }_{\mathrm{p}} \mathrm{CO}_{2}$ in surface ocean waters increases in response to increased atmospheric concentrations of $\mathrm{CO}_{2}$ (Wanninkhof et al. 2009). The gradual acidification affects calcium carbonate producing organisms as $\mathrm{CaCO}_{3}$ dissolves under acidified conditions (Orr et al. 2005; Feely et al. 2009b). Ocean acidification is expressed as the $\mathrm{CaCO}_{3}$ saturation state $(\Omega)$ expressing the concentration of the mineral forming ions $\left(\mathrm{Ca}^{2+}\right.$ and $\left.\mathrm{CO}_{2}{ }^{-3}\right)$ relative to the minerals' equilibrium concentration. The $\Omega$ for the $\mathrm{CaCO}_{3}$ mineral aragonite $\left(\Omega_{\mathrm{Arag}} ; \frac{\mathrm{mol}^{2} / \mathrm{m}^{-3}}{\mathrm{~mol} / \mathrm{m}^{-3}}\right)$ is used as control variable for the PB and becomes critical at 2.9, i.e., ca. 380 ppm (Guinotte and Fabry 2008). To comply with general LCA conventions where increased impact scores are considered negative, the CF for ocean acidification expresses the change in absolute difference between pre-industrial $\Omega_{\text {Arag }}$ levels and $\Omega_{\text {Arag }}$ as a result of a changed emission flux of $\mathrm{CO}_{2}$ and $\mathrm{CO}_{2}$-precursors. Impact scores for ocean acidification can be converted to an absolute $\Omega_{\text {Arag }}$ level by deducting the absolute difference from the pre-industrial $\Omega_{\text {Arag }}$ level $(=3.44)$ to show what the absolute $\Omega_{\text {Arag }}$ level will be as a result of the assessed activity. The $\mathrm{CF}$ takes into account the change in atmospheric $\mathrm{CO}_{2}$ concentration from a change in continuous emission of $\mathrm{CO}_{2}$ or $\mathrm{CO}_{2}$-precursors and the change in ocean chemistry as changing $\Omega_{\text {Arag }}$ from changing atmospheric $\mathrm{CO}_{2}$ concentration. The latter was based on estimates 
Ryberg MW, Owsianiak M, Richardson K, Hauschild MZ (2018) Development of a life-cycle impact assessment methodology linked to the Planetary Boundaries framework. Ecol Indic 88:250-262. doi:

10.1016/j.ecolind.2017.12.065

of seawater system parameters (such as ocean $\mathrm{CO}_{2}$ concentration, $\mathrm{pH}$ and $\Omega_{\mathrm{Arag}}$ ) at different atmospheric $\mathrm{CO}_{2}$ concentrations (Guinotte and Fabry 2008; Feely et al. 2009a). The former was estimated based on an assessment of the RCP2.6 scenario (Meinshausen et al. 2011) with $\mathrm{CO}_{2}$-precursors included via the mass fraction of the precursor that is converted to $\mathrm{CO}_{2}$ (Wenzel and Hauschild 1998; Gillenwater et al. 2006).

\subsubsection{Biogeochemical flows - Nitrogen}

Human induced emissions of reactive nitrogen $(N)$ compounds to the environment have a number of potential impacts, i.e., increased atmospheric $\mathrm{NH}_{3}$ concentrations, radiative forcing by $\mathrm{N}_{2} \mathrm{O}$, groundwater contamination by $\mathrm{NO}_{3}{ }^{-}$, eutrophication of aquatic ecosystems and biodiversity changes (De Vries et al. 2013). CFs for human induced nitrogen fixation were calculated for emissions of $\mathrm{N}$-compounds to freshwater, groundwater and air. Emissions of $\mathrm{N}$-compounds to the environment, as reported in the $\mathrm{LCl}$, were via inverse modelling transformed to equivalent amounts of fixated $\mathrm{N}$. It is important only to select one of the emission compartments for the inverse modelling to avoid double-counting because emissions of $\mathrm{N}$ to different environmental compartments can stem from the same amount of $\mathrm{N}$ fixated. For instance, for agricultural processes, we recommend to use the CFs for emissions to freshwater via runoff or leaching through drains as this is the dominating $\mathrm{N}$ loss route for this process category (Brentrup et al. 2000; Langevin et al. 2010).

\subsubsection{Biogeochemical flows - Phosphorus}

The problem of excessive phosphorus $(\mathrm{P})$ release to the environment is primarily related to eutrophication of lakes and freshwater reservoirs, the risk of ocean anoxia from massive P outflows to marine waters and changes in biodiversity (Rockström et al. 2009b; Steffen et al. 2015). Hence, the PB for P is defined as two control variables: (i) annual mass of $\mathrm{P}$ applied to soil and (ii) annual mass of $\mathrm{P}$ outflow to marine waters.

CFs for phosphorus applied to soil were estimated for substances that are directly lost to surface freshwater as the primary concern was eutrophication of rivers and lakes. Similar to the CF for the N-cycle, annual emissions of $\mathrm{P}$-compounds to the environment were via inverse modelling transformed to equivalents of annual mass of $P$ applied to soil. The relationship between application of $P$ to soil and emissions of $P$ to the environment was estimated with the Annual Phosphorus Loss Estimator v2.4 (Vadas et al. 2009; Vadas et al. 2012; Vadas 2013).

The CFs for global phosphorus outflow to marine waters were estimated as annual outflow of $\mathrm{P}$ to marine ecosystems per unit change in annual emission of $\mathrm{P}$ to freshwater systems. Fate of $\mathrm{P}$ in freshwater and outflow 
Ryberg MW, Owsianiak M, Richardson K, Hauschild MZ (2018) Development of a life-cycle impact assessment methodology linked to the Planetary Boundaries framework. Ecol Indic 88:250-262. doi:

10.1016/j.ecolind.2017.12.065

rate to marine waters was based on transfer coefficients for sedimentation of $P$ in lakes and rivers and $P$ outflow to marine waters (Carpenter and Bennett 2011).

\subsubsection{Land-system change}

The PB for Land-system change focuses on processes in land systems that regulate exchange of energy, water and momentum between the land surface and the atmosphere and expresses the minimum required percentage of forest land area relative to original forest cover (Steffen et al. 2015). Global CFs reflect changes in percentage of potential forest area per unit area of forest transformed and were calculated as the inverse of potential global forest area multiplied with $100 \%$. Thereby, the impact score shows the percentage of potential forest area transformed as a result of the assessed activity, which complies with LCA conventions about considering increasing impact scores as negative. By deducting the impact score from $100 \%$, it is converted to percentage of potential forest area remaining which is directly comparable to the PB control value. The CFs at biome level were defined in the same way, expressing change in percentage of potential forest biome area per change in forest biome area transformed. CFs for the global PB and CFs for the biome level PBs are kept separate because the relative importance of the forest biomes in the PB-framework, as illustrated by the difference in required percentage of forest remaining, cannot be adequately aggregated into a single score expressed in the metric of the global forest PB. It is, therefore, recommended to show impact scores for landsystem change at both global and biome level to get a detailed assessment at both levels.

\subsubsection{Freshwater use}

Freshwater flow is important for sustaining biodiversity and the functions required for maintaining the state of the ecosystem (Poff et al. 2010) and excessive human induced freshwater withdrawal can affect freshwater ecosystems (Smakhtin 2008). Average global freshwater availability is sufficient to remain within the PB but the large spatial and temporal variability in freshwater availability means that PBs at river basin level are exceeded (Hoekstra and Mekonnen 2011). The CF for global freshwater use was defined as $10^{-9} \mathrm{~km}^{3} \mathrm{~m}^{-3}$ to convert the

metric of common $\mathrm{LCl}$ data on water use [i.e. $\mathrm{m}^{3} \mathrm{yr}^{-1}$ ] to the metric of the control variable for the Planetary Boundary on global freshwater use [i.e. $\mathrm{km}^{3} \mathrm{yr}^{-1}$ ].

The CFs for freshwater use at the basin level express the change in share of freshwater flow available for human activities per change in human induced freshwater withdrawal. The calculation of freshwater flow available for human withdrawal was made according to the variable monthly flow (VMF) method (Pastor et al. 2014) using spatially differentiated river basin data on mean monthly natural runoff (Hoekstra and Mekonnen 
Ryberg MW, Owsianiak M, Richardson K, Hauschild MZ (2018) Development of a life-cycle impact assessment methodology linked to the Planetary Boundaries framework. Ecol Indic 88:250-262. doi:

10.1016/j.ecolind.2017.12.065

2011). The VMF method estimates the environmental flow requirements and, thus, the share of freshwater flow which is unavailable for human withdrawal (Pastor et al. 2014). A challenge in development of CFs for freshwater use at river basin level is to have spatial differentiation while also allowing for aggregating spatially differentiated impacts to a single indicator. For freshwater use, the challenge is that averaging over regions is required to estimate a global total single score. Here, a global average may hide important exceedances of PBs at river basin level (Ryberg et al. 2016). To operationalize spatial differentiation of CFs, the river basins were classified into aridity based archetypes, i.e. arid (includes hyper arid), semi-arid and humid (includes subhumid) based on the Aridity Index (UNEP 1997).

Thus, CFs for water withdrawal in arid regions are higher than CFs for water withdrawal in humid regions because water availability is lower in arid regions. The archetype classification allowed for aggregating river basins within the same archetype ensuring that exceedance in water withdrawal in arid regions is not "hidden" by water abundance in humid regions. CFs were also calculated based on the period of water withdrawal, i.e. if water is withdrawn during low, intermediate or high flow months where CFs are larger during low-flow months where water availability is lower. The spatial and temporally differentiated CFs allow for assessing impacts at different spatial and temporal resolutions but cannot be aggregated to a single global score without averaging across spatial and temporal scales and, thereby, losing specific details. It is, therefore, suggested to evaluate impact scores at different spatial and temporal scales, e.g. at global average and at aridity archetype level and, if required, also at river basin level, to get a more detailed basis for decision-making.

\subsubsection{Atmospheric aerosol loading}

Atmospheric aerosol loading stems from emissions of primary and secondary aerosols which can impact global and regional climate systems (Ramanathan et al. 2001; Ramanathan et al. 2005; Boucher et al. 2013). The control variable for atmospheric aerosol loading is the Aerosol Optical Depth (AOD; dimensionless) which expresses the absorption or scattering of solar radiation. Atmospheric aerosol loading is spatially and temporally differentiated because aerosols' life time is normally a few days (Ramanathan et al. 2001; Boucher et al. 2013). CFs were estimated as global averages and for different regions and express the change in AOD per annual mass emission of aerosols. Change in AOD per unit change in mass load was expressed by the aerosols' specific extinction efficiency and mass load was estimated as a function of aerosol life time and the area the aerosol distributes over. It was assumed that aerosols are fully distributed over the regions in which they are emitted and that aerosol mass transfer does not occur between regions. This assumption aligns with the TM5- 
Ryberg MW, Owsianiak M, Richardson K, Hauschild MZ (2018) Development of a life-cycle impact assessment methodology linked to the Planetary Boundaries framework. Ecol Indic 88:250-262. doi:

10.1016/j.ecolind.2017.12.065

FASST source-receptor model (EC-JRC 2016) and the study by Yu et al. (2013) where interregional transport was found to be limited, and at least $86 \%$ and $64 \%$ of changes in aerosol concentration stems from emissions within the assessed regions, respectively. Global average CFs indicate how emissions at different locations affect global AOD over global terrestrial area while regional CFs (Table S9) express regional AOD from emissions within the region. Impact scores for regional CFs cannot be aggregated to a total AOD without averaging across regions because regional AOD depends on the region's area. The regional CFs should, therefore, be evaluated as separate impact scores to evaluate exceedance of any local PBs. 
Ryberg MW, Owsianiak M, Richardson K, Hauschild MZ (2018) Development of a life-cycle impact assessment methodology linked to the Planetary Boundaries framework. Ecol Indic 88:250-262. doi: 10.1016/j.ecolind.2017.12.065

Table 1. Fundamentals of the characterization modelling for each PB impact category in terms of control variable and defined Planetary Boundaries for the concerned Earth System processes from Steffen et al. (2015), and the governing equation used for characterizing the impact of human activities relative to the Planetary Boundary.

\begin{tabular}{|c|c|c|c|c|}
\hline $\begin{array}{l}\text { Impact } \\
\text { category } \\
\text { (Earth } \\
\text { System) }\end{array}$ & $\begin{array}{l}\text { Impact category } \\
\text { (Control variable in PB- } \\
\text { framework) }\end{array}$ & $\begin{array}{l}\text { Planetary } \\
\text { Boundary }\end{array}$ & Governing characterization factor equation & $\begin{array}{l}\text { No. of } \\
\text { elementary } \\
\text { flows } \\
\text { covered }\end{array}$ \\
\hline \multirow[t]{2}{*}{$\begin{array}{l}\text { Climate } \\
\text { change }\end{array}$} & $\begin{array}{l}\text { Energy imbalance at } \\
\text { top-of-atmosphere } \\
{\left[\mathrm{Wm}^{-2}\right] \text { relative to pre- }} \\
\text { industrial level }\end{array}$ & 1 & $\begin{array}{l}C F_{\mathrm{GW}, \mathrm{RF}, \mathrm{x}}\left[\frac{\mathrm{W} / \mathrm{m}^{2}}{\mathrm{~kg} / \mathrm{yr}}\right]=\frac{\Delta R F}{\Delta S_{G H G, x}} \\
\text { Where } \mathrm{RF} \text { is radiative forcing }\left[\mathrm{W} \mathrm{m}^{-2}\right] \text {, and } \mathrm{S}_{\mathrm{GJG}, \mathrm{x}} \text { is annual emission of } \mathrm{GHG} \times\left[\mathrm{kg} \mathrm{yr}^{-1}\right] .\end{array}$ & 18 \\
\hline & $\begin{array}{l}\text { Atmospheric } \mathrm{CO}_{2} \\
\text { concentration }[\mathrm{ppm} \\
\left.\mathrm{CO}_{2}\right]\end{array}$ & 350 & 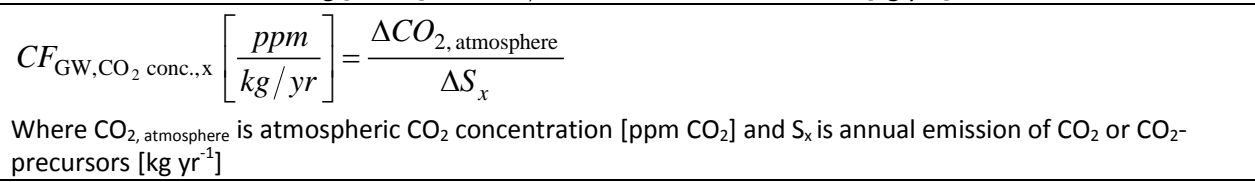 & 7 \\
\hline $\begin{array}{l}\text { Stratospheric } \\
\text { ozone } \\
\text { depletion }\end{array}$ & $\begin{array}{l}\text { Stratospheric } \mathrm{O}_{3} \\
\text { concentration in Dobson } \\
\text { Units [DU] }\end{array}$ & $\begin{array}{l}5 \% \text { reduction } \\
\text { relative to a } \\
\text { pre-industrial } \\
\text { level of } 290 \mathrm{DU} \\
(=275 \mathrm{DU})\end{array}$ & $\begin{array}{l}C F_{O D, \mathrm{x}}\left[\frac{D U}{\mathrm{~kg} / \mathrm{yr}}\right]=\frac{\Delta\left|C_{O 3}\right|}{\Delta E E S C} \times \frac{\Delta E E S C}{\Delta T C L} \times \frac{\Delta T C L}{\Delta S_{x}} \\
\text { Where }\left|\mathrm{C}_{\mathrm{O}}\right| \text { is the absolute difference between pre-industrial stratospheric ozone concentration and ozone } \\
\text { concentration stemming from a change in equivalent effective stratospheric chlorine level, EESC [ppt]. TCL is } \\
\text { total tropospheric chlorine loading equivalent [ppt] and } \mathrm{S} \text { is annual emission of ozone depleting substance [kg } \\
\left.\mathrm{yr}^{-1}\right] .\end{array}$ & 16 \\
\hline $\begin{array}{l}\text { Ocean } \\
\text { acidification }\end{array}$ & $\begin{array}{l}\text { Carbonate ion } \\
\text { concentration, with } \\
\text { respect to aragonite } \\
\text { saturation state }\left[\Omega_{\text {arag }}\right]\end{array}$ & 2.75 & 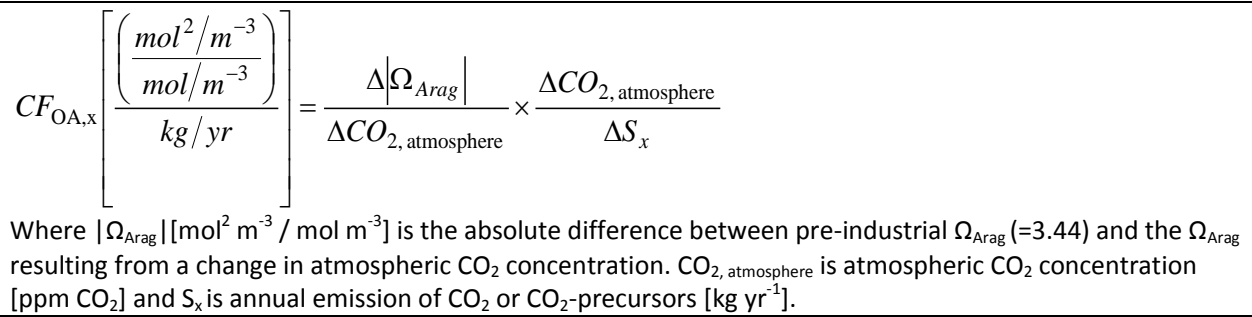 & 7 \\
\hline \multirow[t]{3}{*}{$\begin{array}{l}\text { Biogeo- } \\
\text { chemical } \\
\text { flows }\end{array}$} & $\begin{array}{l}\text { Global: Phosphorus flow } \\
\text { from freshwater system } \\
\text { in to ocean }\left[\mathrm{Tg} \mathrm{P} \mathrm{yr}^{-1}\right]\end{array}$ & 11 & $\begin{array}{l}C F_{\mathrm{P}, \text { global }}\left[\frac{T g_{\text {marine }} / y r}{\mathrm{~kg}_{\mathrm{P} \text { emitted }} / \mathrm{yr}}\right]=1 \times 10^{-9} \times \frac{\Delta P_{\text {marine }}}{\Delta S_{\mathrm{P}-\text { compund emitted }}} \\
\text { Where } \mathrm{P}_{\text {marine }} \text { is annual mass of } \mathrm{P} \text { outflow to marine waters }\left[\mathrm{kg} \mathrm{yr}^{-1}\right] \text { and } \mathrm{S}_{\mathrm{P} \text { compound emitted }} \text { is annual mass of } \mathrm{P} \\
\text { containing compound emitted to the environment }\left[\mathrm{kg} \mathrm{yr}^{-1}\right] \text {. }\end{array}$ & 5 \\
\hline & 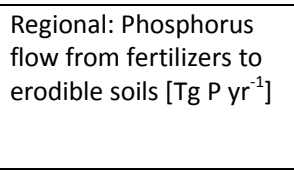 & 26.2 & $\begin{array}{l}C F_{\mathrm{P}, \text { regional }}\left[\frac{T g_{\mathrm{P} \text { applied }} / \mathrm{yr}}{\mathrm{kg}_{\mathrm{P} \text { emitted }} / \mathrm{yr}}\right]=1 \times 10^{-9} \times \frac{\Delta P_{\text {applied }}}{\Delta S_{\mathrm{P}-\text { compund emitted }}} \\
\text { Where } \mathrm{P}_{\text {applied }} \text { is mass of } \mathrm{P} \text { annually applied to erodible soil }\left[\mathrm{kg} \mathrm{yr}^{-1}\right] \text { and } \mathrm{S}_{\mathrm{P} \text { compound emitted is annual mass of } \mathrm{P}} \\
\text { containing compound emitted to the environment }\left[\mathrm{kg} \mathrm{yr}^{-1}\right] \text {. }\end{array}$ & 1 \\
\hline & $\begin{array}{l}\text { Global: Industrial and } \\
\text { intentional biological } \\
\text { fixation of nitrogen [Tg }\end{array}$ & 62 & $C F_{\mathrm{N}, \mathrm{j}}\left[\frac{T g_{\mathrm{N} \text { fixed }} / y r}{k g_{\mathrm{N} \text { emitted }} / y r}\right]=1 \times 10^{-9} \times \frac{\Delta N_{\text {fixated }}}{\Delta S_{\mathrm{N} \text { emitted } \mathrm{j}}}$ & 1 \\
\hline
\end{tabular}


Ryberg MW, Owsianiak M, Richardson K, Hauschild MZ (2018) Development of a life-cycle impact assessment methodology linked to the Planetary Boundaries framework. Ecol Indic 88:250-262. doi: 10.1016/j.ecolind.2017.12.065

\begin{tabular}{|c|c|c|c|c|}
\hline & $\left.\mathrm{N} \mathrm{yr}^{-1}\right]$ & & $\begin{array}{l}\text { Where } \mathrm{N}_{\text {fixated }} \text { is mass of annual human induced } \mathrm{N} \text { fixation }\left[\mathrm{kg} \mathrm{yr}^{-1}\right] \text { and } \mathrm{S}_{\mathrm{N} \text { emitted, }} \text { is annual mass of } \mathrm{N} \text { containing } \\
\text { compounds emitted to environmental compartment } \mathrm{j}\left[\mathrm{kg} \mathrm{yr}^{-1}\right] \text {. }\end{array}$ & \\
\hline \multirow[t]{2}{*}{$\begin{array}{l}\text { Land-system } \\
\text { change }\end{array}$} & $\begin{array}{l}\text { Global: area of forested } \\
\text { land as \% of original } \\
\text { forest cover [\%] }\end{array}$ & $75 \%$ & $\begin{array}{l}C F_{\text {forest global }}\left[\frac{\%}{m^{2}}\right]=\frac{1}{A_{\text {pot, global }}} \times 100 \% \\
\text { Where } A_{\text {pot, global }} \text { is potential global forest area }\left[10^{6} \mathrm{~km}^{2}\right]\end{array}$ & 1 \\
\hline & $\begin{array}{l}\text { Biome: area of forested } \\
\text { land as \% of potential } \\
\text { forest }[\%]\end{array}$ & $\begin{array}{l}\text { Tropical: } 85 \% \\
\text { Temperate: } \\
50 \% \\
\text { Boreal:85\% }\end{array}$ & $\begin{array}{l}C F_{\text {forest biome }}\left[\frac{\%}{m^{2}}\right]=\frac{1}{A_{\text {pot, biome }}} \times 100 \% \\
\text { Where } A_{\text {pot, biome_ }} \text { is potential area of forest biome i }\left[10^{6} \mathrm{~km}^{2}\right] .\end{array}$ & 3 \\
\hline \multirow[t]{2}{*}{$\begin{array}{l}\text { Freshwater } \\
\text { use }\end{array}$} & $\begin{array}{l}\text { Global: Maximum } \\
\text { amount of consumptive } \\
\text { blue water use }\left[\mathrm{km}^{3} \mathrm{yr}^{-1}\right]\end{array}$ & 4000 & $\begin{array}{l}C F_{\text {FrW global }}\left[\frac{\mathrm{km}^{3} / \mathrm{yr}}{\mathrm{m}^{3} / \mathrm{yr}}\right]=\frac{\Delta V_{\mathrm{FrW}} \text { withdrawal }}{\Delta S_{\mathrm{FrW}} \text { withdrawal }} \\
\begin{array}{l}\text { Where } V_{\mathrm{FrW}} \text { withdrawa i global freshwater volume available for withdrawal }\left[\mathrm{km}^{3} \mathrm{yr}^{-1}\right], \mathrm{S}_{\mathrm{FrW}} \text { withdrawal is annual } \\
\text { volume of freshwater withdrawn as a result of human activities }\left[\mathrm{m}^{3} \mathrm{yr}^{-1}\right]\end{array}\end{array}$ & 1 \\
\hline & $\begin{array}{l}\text { Basin: Blue water } \\
\text { withdrawal as \% of } \\
\text { mean monthly flow } \\
\text { (MMF) }\end{array}$ & $\begin{array}{l}\text { Low-flow } \\
\text { month: } 25 \% \\
\text { Intermediate- } \\
\text { flow month: } \\
30 \% \\
\text { High-flow } \\
\text { month: } 55 \%\end{array}$ & $\begin{array}{l}C F_{\text {freshwater use, } \mathrm{x}}\left[\frac{y r}{\mathrm{~m}^{3}}\right]=\frac{\Delta W A_{x}}{\Delta S_{\text {withdrawn, } x}} \\
{\mathrm{Where} \mathrm{WA}_{\mathrm{x}} \text { is available annual volume of freshwater for human induced withdrawal in spatial archetype } \mathrm{x}\left[\mathrm{m}^{3}\right.}^{\left.\mathrm{yr}^{-1}\right] \text { and } \mathrm{S}_{\text {withdrawn, }} \text { is annual volume of human induced freshwater withdrawal in spatial archetype } \mathrm{x}\left[\mathrm{m}^{3} \mathrm{yr}^{-1}\right] .} \\
\text { Default CFs were based on annual } \mathrm{LCl} \text {, but CFs with monthly temporal resolution were also developed for } \mathrm{LCl} \\
\text { with specification on monthly withdrawals. }\end{array}$ & 12 \\
\hline \multirow[t]{2}{*}{$\begin{array}{l}\text { Atmospheric } \\
\text { aerosol } \\
\text { loading }\end{array}$} & $\begin{array}{l}\text { Global: Aerosol Optical } \\
\text { Depth (AOD) }\end{array}$ & $\begin{array}{l}\text { While no } \\
\text { Planetary } \\
\text { Boundary has } \\
\text { been set, CFs } \\
\text { for global AOD } \\
\text { were developed } \\
\text { to prepare for a } \\
\text { future global } \\
\text { Planetary } \\
\text { Boundary in the } \\
\text { same metric as } \\
\text { the regional } \\
\text { boundary }\end{array}$ & $\begin{array}{l}C F_{\text {Aerosol,global, } \mathrm{x}}\left[\frac{\text { dimensionless }}{\mathrm{kg} / \mathrm{yr}}\right]=\frac{\Delta A O D}{\Delta m_{\text {atm }}} \times \frac{\Delta m_{\text {atm }}}{\Delta S_{x}} \\
\text { Where AOD is aerosol optical depth [dimensionless], } \mathrm{m}_{\mathrm{atm}} \text { is aerosol mass load over global terrestrial area and } \\
\left.\mathrm{S} \text { is annual emission of the aerosol [ } \mathrm{kg}_{\mathrm{yr}} \mathrm{yr}^{-1}\right]\end{array}$ & 13 \\
\hline & $\begin{array}{l}\text { Regional: AOD as a } \\
\text { seasonal average over a } \\
\text { region with South Asian } \\
\text { Monsoon used as case } \\
\text { study [AOD] }\end{array}$ & 0.25 & $\begin{array}{l}C F_{\text {Aerosol, regiona, } \mathrm{xl}}\left[\frac{\text { dimensionless }}{\mathrm{kg} / \mathrm{yr}}\right]=\frac{\Delta A O D}{\Delta m_{\text {atm }}} \times \frac{\Delta m_{a t m}}{\Delta S_{\mathrm{x}}} \\
\text { Where AOD is aerosol optical depth [dimensionless], } \mathrm{m}_{\mathrm{atm}} \text { is aerosol mass load over regional area and } \mathrm{S} \text { is } \\
\left.\text { annual emission of the aerosol [ } \mathrm{kg} \mathrm{yr}^{-1}\right]\end{array}$ & 13 \\
\hline
\end{tabular}


Ryberg MW, Owsianiak M, Richardson K, Hauschild MZ (2018) Development of a life-cycle impact assessment methodology linked to the Planetary Boundaries framework. Ecol Indic 88:250-262. doi: 10.1016/j.ecolind.2017.12.065

\subsection{Comparison of PB-LCIA with ILCD-LCIA}

An evaluation of whether the PB-LCIA would give similar or different conclusion compared to a conventional LCIA methodology was done by comparing results of the PB-LCIA with results calculated with the 'ILCD 2011' LCIA methodology (referred to as ILCD-LCIA) recommended by the ILCD (EC-JRC 2011; Hauschild et al. 2013). The comparison was done by comparing impact scores for impact categories in PBLCIA with scores for similar categories in ILCD-LCIA, based on similarities in the environmental pressure and elementary flows covered in the impact category (Table 2). For instance, ocean acidification in PB-LCIA was compared with climate change in ILCD-LCIA because ocean acidification is driven by emissions of $\mathrm{CO}_{2}$ and $\mathrm{CO}_{2}$-precursors. We stress that this exercise was done only to compare results of the two methods when employed in regular life cycle assessments of products and systems. The reader should note, however, that the impact categories and their CFs should otherwise not be matched 1:1 as they differ in several areas (e.g. different units, position in impact pathway, and area of protection).

Table 2. Overview of comparison between impact categories in PB-LCIA and ILCD-LCIA and the rationale for comparing the particular impact categories.

\begin{tabular}{|c|c|c|}
\hline ILCD-LCIA impact category & PB-LCIA impact category & Rationale for comparing impact categories \\
\hline Climate change & Climate change $-\mathrm{CO}_{2}$ concentration & Both express climate change \\
\hline Climate change & Climate change - Energy imbalance & Both express climate change \\
\hline Climate change & Ocean acidification & $\begin{array}{l}\text { Ocean acidification is linked to the drivers of climate changes because } \\
\text { ocean acidification is a consequence of anthropogenic } \mathrm{CO}_{2} \text { emissions } \\
\text { (Feely et al. 2004; Doney et al. 2009). }\end{array}$ \\
\hline Ozone depletion & Stratospheric ozone depletion & Both express ozone depletion. \\
\hline Land use & Land-system change - Global & Both express land use. \\
\hline Water resource depletion & Freshwater use - River basins & Both express freshwater use. \\
\hline Photochemical ozone formation & Atmospheric aerosol loading & $\begin{array}{l}\text { The PB was compared with "Photochemical ozone formation" } \\
\text { because both include emissions of aerosols to the atmosphere. } \\
\text { However, the area of concern for the two indicators differ slightly, } \\
\text { where "Photochemical ozone formation" is about ground level ozone } \\
\text { formation (and concentration) and how this affects humans and } \\
\text { ecosystems (EC-JRC 2010b; Hauschild and Huijbregts 2015; van Zelm } \\
\text { et al. 2016), while "Atmospheric aerosol loading" is about aerosols in } \\
\text { the atmosphere and how the increased loading may lead to undesired } \\
\text { effects due to changes in solar radiation and regional ocean- } \\
\text { atmosphere circulation (Steffen et al. 2015). Hence, the two impact } \\
\text { categories differ in their area of concern; however, they have been } \\
\text { compared in this study due to their similarities in impact pathway and } \\
\text { to allow a comparison of results for aerosols between PB-LCIA and } \\
\text { ILCD-LCIA. }\end{array}$ \\
\hline Freshwater eutrophication & Biogeochemical flows - Regional P & $\begin{array}{l}\text { The PB was compared with "Freshwater eutrophication" because in } \\
\text { majority of LCIA methods, phosphorus is considered the primary } \\
\text { contributor to freshwater eutrophication (EC-JRC 2011; Goedkoop et } \\
\text { al. 2013). This is because phosphorous is the predominant growth- } \\
\text { limiting nutrient for freshwater ecosystems (Schindler 1977; } \\
\text { Carpenter et al. 1998; Smith 2003) and thus most problematic in } \\
\text { terms of freshwater eutrophication. }\end{array}$ \\
\hline Marine eutrophication & Biogeochemical flows - N & $\begin{array}{l}\text { The PB was compared with "Marine eutrophication" because in } \\
\text { majority of LCIA methods, nitrogen is considered the primary } \\
\text { contributor to marine eutrophication (EC-JRC 2011; Goedkoop et al. } \\
\text { 2013; Cosme et al. 2015). This is because nitrogen is, in many cases, } \\
\text { the predominant growth-limiting nutrient for marine ecosystems (i.e. } \\
\text { estuaries and coastal systems) (Carpenter et al. 1998; Vitousek et al. } \\
\text { 2002; Howarth and Marino 2006) and thus most problematic in terms }\end{array}$ \\
\hline
\end{tabular}


Ryberg MW, Owsianiak M, Richardson K, Hauschild MZ (2018) Development of a life-cycle impact assessment methodology linked to the Planetary Boundaries framework. Ecol Indic 88:250-262. doi: 10.1016/j.ecolind.2017.12.065

Impact scores for the PB-LCIA and the compared impact categories in ILCD-LCIA were calculated and ranked for 10,687 unit processes in the ecoinvent v. 3.1 consequential life cycle unit process database (Weidema et al. 2013). The unit processes in ecoinvent give information on the emissions and resource uses per unit output from the process. For use with the PB-LCIA, the process output was interpreted as emissions and resource uses per annual unit output to comply with the PB-LCIA's requirement for annual flows. Pearson correlation and Spearman rank correlation analyses were performed on the absolute and ranked impact scores respectively to evaluate correlations between magnitude and ranking of impact scores. A low Pearson correlation coefficient indicates a low correlation between magnitudes of the impact scores of the unit processes; a low Spearman rank correlation coefficient indicates a low correlation between the rankings of unit processes. For the comparison, unit processes were divided into groups, i.e. 'materials', 'energy', 'transport', and 'processing' to identify if differences between LCIA methodologies were more pronounced for certain process groups.

\section{Results}

\subsection{Characterization Factors in PB-LCIA}

The derived CFs for the PB-LCIA are listed in Table 3 and include CFs for 85 elementary flows covering the most prominent contributors to each of the included impact categories in Table 1. Moreover, the calculated impact scores for the unit processes in ecoinvent generally span over 10 to 13 orders of magnitude depending on the impact category which is comparable to the span in conventional LCIA methods (Laurent et al. 2012).

Table 3. List of estimated characterization factors for the Planetary Boundaries included in the PB-LCIA methodology

\begin{tabular}{|c|c|c|c|c|c|}
\hline $\begin{array}{l}\text { Earth System } \\
\text { process }\end{array}$ & Control variable & Environmental flow & $\begin{array}{l}\text { Emission } \\
\text { compartment }\end{array}$ & $\begin{array}{l}\text { Characterization } \\
\text { factor }\end{array}$ & Unit \\
\hline \multirow[t]{13}{*}{ Climate change } & \multirow{13}{*}{$\begin{array}{l}\text { Energy imbalance at } \\
\text { top-of-atmosphere }\end{array}$} & $\mathrm{CO}_{2}$ & Air & $3.53 \square 10^{-13}$ & W yr m ${ }^{-2} \mathrm{~kg}^{-1}$ \\
\hline & & $\mathrm{CO}_{2}$, land transformation & Air & $1.18 \square 10^{-15}$ & $W \mathrm{~m}^{-2} \mathrm{~kg}^{-1}$ \\
\hline & & $\mathrm{CH}_{4}$ & Air & $1.59 \square 10^{-12}$ & W yr m ${ }^{-2} \mathrm{~kg}^{-1}$ \\
\hline & & $\mathrm{N}_{2} \mathrm{O}$ & Air & $4.64 \square 10^{-11}$ & W yr m ${ }^{-2} \mathrm{~kg}^{-1}$ \\
\hline & & $\mathrm{CO}$ & Air & $2.74 \square 10^{-13}$ & W yr m${ }^{-2} \mathrm{~kg}^{-1}$ \\
\hline & & NMVOC, hydrocarbons & Air & $1.06 \square 10^{-12}$ & W yr m${ }^{-2} \mathrm{~kg}^{-1}$ \\
\hline & & NMVOC, partly oxidized hydrocarbons & Air & $7.07 \square 10^{-13}$ & W yr m ${ }^{-2} \mathrm{~kg}^{-1}$ \\
\hline & & NMVOC, partly chlorinated hydrocarbons & Air & $3.53 \square 10^{-13}$ & W yr m${ }^{-2} \mathrm{~kg}^{-1}$ \\
\hline & & CFC-11 & Air & $4.79\left[10^{-10}\right.$ & W yr m${ }^{-2} \mathrm{~kg}^{-1}$ \\
\hline & & CFC-12 & Air & $1.49 \square 10^{-9}$ & W yr m ${ }^{-2} \mathrm{~kg}^{-1}$ \\
\hline & & CFC-13 & Air & $8.61\left[10^{-9}\right.$ & W yr m${ }^{-2} \mathrm{~kg}^{-1}$ \\
\hline & & CFC-113 & Air & $7.65\left[10^{-10}\right.$ & W yr m ${ }^{-2} \mathrm{~kg}^{-1}$ \\
\hline & & CFC-114 & Air & $1.94 \square 10^{-9}$ & W yr m ${ }^{-2} \mathrm{~kg}^{-1}$ \\
\hline
\end{tabular}


Ryberg MW, Owsianiak M, Richardson K, Hauschild MZ (2018) Development of a life-cycle impact assessment methodology linked to the Planetary Boundaries framework. Ecol Indic 88:250-262. doi: 10.1016/j.ecolind.2017.12.065

\begin{tabular}{|c|c|c|c|c|c|}
\hline & & CFC-115 & Air & $7.43 \square 10^{-9}$ & W yr m ${ }^{-2} \mathrm{~kg}^{-1}$ \\
\hline & & $\mathrm{NF}_{3}$ & Air & $7.92 \square 10^{-9}$ & W yr m ${ }^{-2} \mathrm{~kg}^{-1}$ \\
\hline & & $\mathrm{SF}_{6}$ & Air & $6.71 \square 10^{-8}$ & W yr m ${ }^{-2} \mathrm{~kg}^{-1}$ \\
\hline & & HCFC-21 & Air & $1.39 \square\left[0^{-11}\right.$ & W yr m ${ }^{-2} \mathrm{~kg}^{-1}$ \\
\hline & & HCFC-22 & Air & $1.63 \square 10^{-10}$ & W yr m ${ }^{-2} \mathrm{~kg}^{-1}$ \\
\hline & \multirow{7}{*}{$\begin{array}{l}\text { Atmospheric } \mathrm{CO}_{2} \\
\text { concentration }\end{array}$} & $\mathrm{CO}_{2}$ & Air & $2.69 \square 10^{-11}$ & ppm yr kg ${ }^{-1}$ \\
\hline & & $\mathrm{CO}$ & Air & $4.23 \square 10^{-11}$ & ppm yr kg ${ }^{-1}$ \\
\hline & & $\mathrm{CH}_{4}$ & Air & $7.40 \square 10^{-11}$ & ppm yr kg ${ }^{-1}$ \\
\hline & & NMVOC, hydrocarbons & Air & $8.07 \square 10^{-11}$ & ppm yr kg ${ }^{-1}$ \\
\hline & & NMVOC, partly oxidized hydrocarbons & Air & $5.38 \square 10^{-11}$ & ppm yr kg ${ }^{-1}$ \\
\hline & & NMVOC, partly chlorinated hydrocarbons & Air & $2.69 \square 10^{-11}$ & ppm yr kg ${ }^{-1}$ \\
\hline & & $\mathrm{CO}_{2}$, land transformation & Air & $8 . 9 7 \longdiv { 1 0 ^ { - 1 4 } }$ & $\mathrm{ppm} \mathrm{kg}^{-1}$ \\
\hline \multirow{16}{*}{\multicolumn{2}{|c|}{ Stratospheric ozone depletion }} & CFC-11 & Air & $7.85 \square 10^{-9}$ & DU yr kg ${ }^{-1}$ \\
\hline & & CFC-12 & Air & $7.34 \square 10^{-9}$ & DU yr kg ${ }^{-1}$ \\
\hline & & CFC-113 & Air & $4.91 \square 10^{-9}$ & DU yr kg ${ }^{-1}$ \\
\hline & & Halon- 1211 & Air & 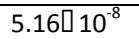 & DU yr kg ${ }^{-1}$ \\
\hline & & Halon-1301 & Air & $1.15 \square 10^{-7}$ & DU yr kg ${ }^{-1}$ \\
\hline & & CFC-10, Carbon Tetrachloride & Air & $5.74 \square 10^{-9}$ & DU yr kg ${ }^{-1}$ \\
\hline & & HCFC-140, 1,1,1 -Trichloroethane & Air & $1.32 \square 10^{-9}$ & DU yr kg ${ }^{-1}$ \\
\hline & & HCFC-22 & Air & $4.83 \square 10^{-10}$ & DU yr kg ${ }^{-1}$ \\
\hline & & HCFC-141b & Air & $1.07 \square 10^{-9}$ & DU yr kg ${ }^{-1}$ \\
\hline & & HCFC-142b & Air & 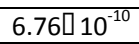 & DU yr kg ${ }^{-1}$ \\
\hline & & Halon 1001, Methyl Bromide & Air & 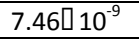 & DU yr kg ${ }^{-1}$ \\
\hline & & CFC-114 & Air & $3 . 6 4 \longdiv { 1 0 ^ { - 9 } }$ & DU yr kg ${ }^{-1}$ \\
\hline & & CFC-115 & Air & $3.99 \square 10^{-9}$ & DU yr kg ${ }^{-1}$ \\
\hline & & Halon 1202 & Air & $1.14 \square 10^{-8}$ & DU yr kg ${ }^{-1}$ \\
\hline & & Halon 2402 & Air & $5.39 \square 10^{-8}$ & DU yr kg ${ }^{-1}$ \\
\hline & & R-40, methyl chloride & Air & $4.03 \square 10^{-10}$ & DU yr kg ${ }^{-1}$ \\
\hline \multirow{7}{*}{\multicolumn{2}{|c|}{ Ocean acidification }} & $\mathrm{CO}_{2}$ & Air & $8.22 \square 10^{-14}$ & $\mathrm{~mol} \mathrm{yr} \mathrm{kg}^{-1}$ \\
\hline & & $\mathrm{CO}$ & Air & $1.29 \square 10^{-13}$ & $\mathrm{~mol} \mathrm{yr} \mathrm{kg}^{-1}$ \\
\hline & & $\mathrm{CH}_{4}$ & Air & $2.26 \square 10^{-13}$ & $\mathrm{~mol} \mathrm{yr} \mathrm{kg}^{-1}$ \\
\hline & & NMVOC, hydrocarbons & Air & $2 . 4 7 \longdiv { 1 0 ^ { - 1 3 } }$ & $\mathrm{mol} \mathrm{yr} \mathrm{kg}^{-1}$ \\
\hline & & NMVOC, partly oxidized hydrocarbons & Air & $1.64 \square 10^{-13}$ & $\mathrm{~mol} \mathrm{yr} \mathrm{kg}^{-1}$ \\
\hline & & NMVOC, partly chlorinated hydrocarbons & Air & $8.22 \square 10^{-14}$ & $\mathrm{~mol} \mathrm{yr} \mathrm{kg}^{-1}$ \\
\hline & & $\mathrm{CO}_{2}$, land transformation & Air & $2.74 \square 10^{-16}$ & $\mathrm{~mol} \mathrm{~kg}^{-1}$ \\
\hline \multirow[t]{7}{*}{ Biogeochemical flows } & \multirow{5}{*}{$\begin{array}{l}\text { N cycle: } \\
\text { Global: } \\
\text { Industrial and } \\
\text { intentional } \\
\text { biological } \\
\text { fixation of } \mathrm{N}\end{array}$} & $\mathrm{NO}_{\mathrm{x}}$ & Air & $3.04 \square 10^{-10}$ & 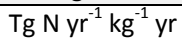 \\
\hline & & $\mathrm{NH}_{3}$ & Air & $8.22 \square 10^{-10}$ & $\operatorname{TgN~} \mathrm{yr}^{-1} \mathrm{~kg}^{-1} \mathrm{yr}$ \\
\hline & & $\mathrm{N}$-tot & Freshwater & $2.44 \square 10^{-8}$ & $\operatorname{TgN~} \mathrm{Nr}^{-1} \mathrm{~kg}^{-1} \mathrm{yr}$ \\
\hline & & $\mathrm{NO}_{3}^{-}$ & Freshwater & $5.51 \square 10^{-9}$ & $\operatorname{Tg~N~yr}^{-1} \mathrm{~kg}^{-1} \mathrm{yr}$ \\
\hline & & $\mathrm{NO}_{3}^{-}$ & Groundwater & $6.45 \square 10^{-10}$ & $\mathrm{Tg} \mathrm{N} \mathrm{yr} \mathrm{kg}^{-1} \mathrm{yr}$ \\
\hline & $\begin{array}{l}\text { P flow from } \\
\text { fertilizers to } \\
\text { erodible soils }\end{array}$ & Phosphorus & Freshwater & $3.68 \square 10^{-8}$ & $\mathrm{TgP} \mathrm{Pr}^{-1} \mathrm{~kg}^{-1} \mathrm{yr}$ \\
\hline & $\begin{array}{l}\text { Global: P flow } \\
\text { from } \\
\text { freshwater } \\
\text { systems into } \\
\text { the ocean }\end{array}$ & Phosphorus & Freshwater & $8.61 \square 10^{-10}$ & $\mathrm{TgP} \mathrm{Pr}^{-1} \mathrm{~kg}^{-1} \mathrm{yr}$ \\
\hline \multirow[t]{4}{*}{ Land-system change } & $\begin{array}{l}\text { Global: area of } \\
\text { forested land }\end{array}$ & Forest transformation & Resource & $1.56 \square 10^{-12}$ & $\% \mathrm{~m}^{-2}$ \\
\hline & Biome: area of & Boreal forest transformation & Resource & $4.44 \square 10^{-12}$ & $\% \mathrm{~m}^{-2}$ \\
\hline & forested land & Temperate forest transformation & Resource & $5 . 2 6 \longdiv { 1 0 ^ { - 1 2 } }$ & $\% \mathrm{~m}^{-2}$ \\
\hline & & Tropical forest transformation & Resource & $4.41\left[10^{-12}\right.$ & $\% \mathrm{~m}^{-2}$ \\
\hline \multirow[t]{6}{*}{ Freshwater use } & $\begin{array}{l}\text { Global: } \\
\text { maximum } \\
\text { amount of } \\
\text { consumptive } \\
\text { blue water }\end{array}$ & Global & Resource & $1.00 \square 10^{-9}$ & $\mathrm{~km}^{3} \mathrm{~m}^{-3}$ \\
\hline & \multirow{5}{*}{$\begin{array}{l}\text { River basin: } \\
\text { blue water } \\
\text { withdrawal }\end{array}$} & Arid - Low flow month & Resource & $1.21 \square 10^{-9}$ & $\mathrm{yr} \mathrm{m}^{-3}$ \\
\hline & & Arid - Intermediary flow month & Resource & $1.87 \square 10^{-10}$ & $\mathrm{yr} \mathrm{m}^{-3}$ \\
\hline & & Arid - High flow month & Resource & $1 . 6 7 \longdiv { 1 0 ^ { - 1 1 } }$ & $\mathrm{yr} \mathrm{m}^{-3}$ \\
\hline & & Arid - Average annual flow month & Resource & $1.51\left[10^{-11}\right.$ & $\mathrm{yr} \mathrm{m}^{-3}$ \\
\hline & & Semi-arid - Low flow month & Resource & $4.51 \square 10^{-11}$ & $\mathrm{yr} \mathrm{m}^{-3}$ \\
\hline
\end{tabular}


Ryberg MW, Owsianiak M, Richardson K, Hauschild MZ (2018) Development of a life-cycle impact assessment methodology linked to the Planetary Boundaries framework. Ecol Indic 88:250-262. doi: 10.1016/j.ecolind.2017.12.065

\begin{tabular}{|c|c|c|c|c|c|}
\hline & & Semi-arid - Intermediary flow month & Resource & $7.92 \square 10^{-12}$ & $\mathrm{yr} \mathrm{m}^{-3}$ \\
\hline & & Semi-arid - High flow month & Resource & $1.17 \square 10^{-12}$ & $\mathrm{yr} \mathrm{m}^{-3}$ \\
\hline & & Semi-arid - Average annual flow month & Resource & $9.97 \square 10^{-13}$ & $\mathrm{yr} \mathrm{m}^{-3}$ \\
\hline & & Humid - Low flow month & Resource & $4.54 \square 10^{-12}$ & $\mathrm{yr} \mathrm{m}^{-3}$ \\
\hline & & Humid - Intermediary flow month & Resource & $6.30 \square 10^{-13}$ & $\mathrm{yr} \mathrm{m}^{-3}$ \\
\hline & & Humid - High flow month & Resource & $8.82 \square 10^{-14}$ & $\mathrm{yr} \mathrm{m}^{-3}$ \\
\hline & & Humid - Average annual flow month & Resource & $7.61\left[10^{-14}\right.$ & $\mathrm{yr} \mathrm{m}^{-3}$ \\
\hline \multirow{13}{*}{$\begin{array}{l}\text { Atmospheric aerosol } \\
\text { loading }\end{array}$} & \multirow{13}{*}{$\begin{array}{l}\text { AOD (Global } \\
\text { CFs shown) }\end{array}$} & $\mathrm{SO}_{4}^{2-}$ & Air & $1.67 \square 10^{-13}$ & $\mathrm{yr} \mathrm{kg}^{-1}$ \\
\hline & & $\mathrm{SO}_{2}$ & Air & $6.84 \square 10^{-14}$ & $\mathrm{yr} \mathrm{kg}^{-1}$ \\
\hline & & Dimethyl sulfide & Air & $2.49 \square 10^{-14}$ & $\mathrm{yr} \mathrm{kg}^{-1}$ \\
\hline & & $\mathrm{PM}_{2.5}$ & Air & $5.20\left[10^{-13}\right.$ & $\mathrm{yr} \mathrm{kg}^{-1}$ \\
\hline & & $\mathrm{PM}_{1}$ & Air & $1.08\left[10^{-11}\right.$ & $\mathrm{yr} \mathrm{kg}^{-1}$ \\
\hline & & $\mathrm{PM}_{10}$ & Air & $9.69\left[10^{-15}\right.$ & $\mathrm{yr} \mathrm{kg}^{-1}$ \\
\hline & & $\begin{array}{l}\text { Generic Carbon aerosols (e.g. organic } \\
\text { carbon) }\end{array}$ & Air & $1.07\left[10^{-13}\right.$ & $\mathrm{yr} \mathrm{kg}^{-1}$ \\
\hline & & Black carbon (e.g. soot) & Air & $1.11\left[10^{-13}\right.$ & $\mathrm{yr} \mathrm{kg}^{-1}$ \\
\hline & & $\mathrm{NO}_{3}$, Nitrate & Air & $9.73 \square 10^{-14}$ & $\mathrm{yr} \mathrm{kg}^{-1}$ \\
\hline & & NMVOC, urban & Air & $4.83 \square 10^{-15}$ & $\mathrm{yr} \mathrm{kg}^{-1}$ \\
\hline & & NMVOC, rural & Air & $1.93 \square 10^{-14}$ & $\mathrm{yr} \mathrm{kg}^{-1}$ \\
\hline & & $\mathrm{NO}_{2}$ & Air & $3.67 \square 10^{-14}$ & $\mathrm{yr} \mathrm{kg}^{-1}$ \\
\hline & & $\mathrm{NO}_{\mathrm{x}}$ & Air & $3.67 \square 10^{-14}$ & $\mathrm{yr} \mathrm{kg}^{-1}$ \\
\hline
\end{tabular}

\subsection{Comparison of PB-LCIA with ILCD-LCIA}

The comparison of the PB-LCIA with ILCD-LCIA showed that Impact categories generally correlated well in terms of ranking unit processes with Spearman rank correlation coefficients above 0.85 for all impact categories except "biogeochemical flows - Regional P" with 0.61. The correlation between magnitude of impact scores was also found to be reasonable with Pearson correlation coefficients above 0.97 for all impact categories except "Land-system change" and "biogeochemical flows - Regional P" with 0.27 and 0.51 , respectively. This indicates that the overall ranking of processes is similar for the two methods. Hence, in an LCA, both methods would generally give a similar estimate of which processes contribute most to environmental burdens. Though the two methods are found to give similar estimate of process contributions the added value of using the PB-LCIA relative to ILCD-LCIA is presented in Section 4.1.3. Figure 1 shows the comparison of ranking of impact categories using the PB-LCIA and ILCD-LCIA for three impact categories representing the general trends in rank correlation. The climate driven impact categories and ozone depletion generally showed good correlation in ranking of the unit processes. This was due to similarities in derivation of characterization models where fate models for both LCIA methods are based on recommendations by IPCC and WMO for climate change and ozone depletion, respectively. The correlation between "photochemical ozone formation" and "atmospheric aerosol loading" showed lower correlation, primarily for material production (primarily wood and biofuel related processes) and processing (mainly waste treatment). This was primarily due to a difference in coverage of environmental flows. For example, "atmospheric aerosol loading" includes particulate matter as this contributes to aerosol loading, while particulate matter is not included for "photochemical ozone formation" as particulate matter does not 
Ryberg MW, Owsianiak M, Richardson K, Hauschild MZ (2018) Development of a life-cycle impact assessment methodology linked to the Planetary Boundaries framework. Ecol Indic 88:250-262. doi: 10.1016/j.ecolind.2017.12.065

contribute to the formation of photochemical ozone. The low Pearson correlation coefficient and Spearman rank correlation coefficient for "biogeochemical flows - Regional P" was almost independent of the unit process category, although the lowest Spearman rank correlation was found for unit processes relating to material production (mainly fuel and wood production) processing of waste, and energy production (primarily from coal and lignite). Indeed, the low correlations were primarily due to differences in coverage of elementary flows where PB-LCIA only includes emission of P compounds to freshwater while ILCD-LCIA includes other emissions routes, such as phosphate to groundwater. For instance, this was the case for the difference in ranking of electricity from coal and lignite where P emitted to groundwater is not considered in the PB-LCIA as the concern is emissions to freshwater compartments.
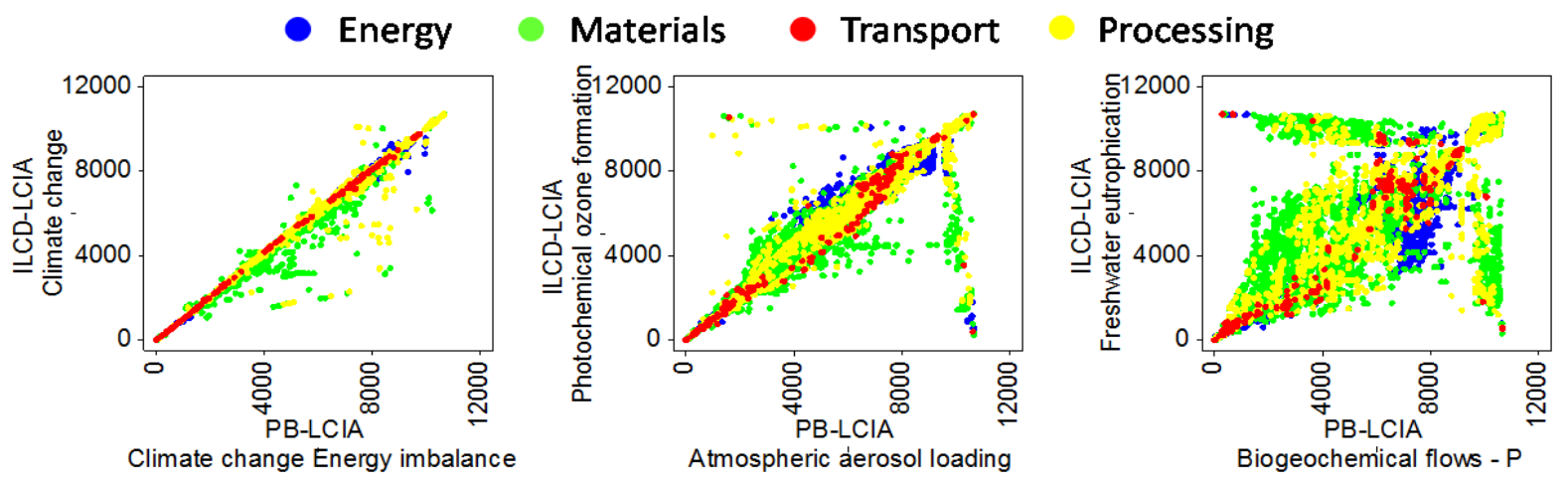

Figure 1. Comparison of PB-LCIA and the ILCD-LCIA in ranking of impact scores between compared impact categories for unit processes from the ecoinvent life cycle inventory database.

\section{Discussion}

\subsection{Applicability}

A PB-LCIA method with a new set of CFs for life cycle impact categories corresponding to control variables in the PB-framework were developed in this study. As a consequence, new requirements for the application of the PB-LCIA arise because the goal of an LCA using the PB-LCIA, and the proposed characterization modelling framework differs from conventional LCAs. Moreover, the new requirements and the use of the PB-framework introduce a number of new aspects with regards to interpretation of results from an LCA using the PB-LCIA.

\subsubsection{Goal definition}

The PB-LCIA was developed to allow for relating impacts of activities to the Planetary Boundaries. Thus, the goal of an LCA using the PB-LCIA is to evaluate how the assessed activity contributes or may contribute to occupying the safe operating space and to what extent the share of the operating space occupied by the 
Ryberg MW, Owsianiak M, Richardson K, Hauschild MZ (2018) Development of a life-cycle impact assessment methodology linked to the Planetary Boundaries framework. Ecol Indic 88:250-262. doi: 10.1016/j.ecolind.2017.12.065

assessed function can be considered environmentally sustainable. Additional goals from the assessment may be to assess the level of environmental improvements required for the assessed function to be environmentally sustainable and to test whether planned or potential environmental improvements are sufficient or if further and more ambitious improvements are required for the activity to be environmentally sustainable. This is in contrast to conventional LCAs, where the goal normally is to compare potential impacts of different ways to fulfill the same FU or to identify where in a product lifecycle impacts occur (EC-JRC 2010a).

\subsubsection{Scope definition and life cycle inventory modelling}

A requirement for assessments where absolute values are important is that the scope of the assessment should cover all processes linked to fulfilling the FU to provide a comprehensive account of the assessed activity's impacts. This requirement is already given for LCAs where the goal is to provide a descriptive environmental account of a product, e.g. Product Environmental Footprints (EC-JRC 2010a). However, this comprehensiveness is not required for comparative LCAs, where identical processes and life-cycle stages can be excluded as only the differences between the compared systems are relevant for comparing the environmental performance (EC-JRC 2010a). Thus, the PB-LCIA can be used for comparative LCAs but still requires a comprehensive $\mathrm{LCl}$ if the goal is to also provide a comprehensive account of the assessed activity's environmental performance relative to the PBs.

To express impact scores in the metrics of the PB control variables, the new characterization models require a continuous constant input for the LCIA. This aspect must be reflected in the definition of the FU and the LCI-modelling. According to the LCA guidelines by the ILCD (EC-JRC 2010a), the FU should include the function provided, its quantity, the duration, and to what quality the function is provided. Indeed, where finite time duration is often applied when defining the FU in conventional LCAs, when applying the PB-LCIA, it is a requirement that the duration specified in the FU should be to provide the function continuously over time. Consequentially, elementary flows should be expressed per time duration (e.g. mass time ${ }^{-1}$ ), i.e. as continuous flows that allows modelling changes in environmental states and flow rates. For application with existing LCA software and LCl databases this means that the FU should be scaled to one year to give results that show potential impacts associated with continuous annual fulfillment of the FU. For instance, a conventional FU for mobility could be defined as traveling 25,000 km each year for 10 years while the FU using the PB-LCIA should be defined as traveling 25,000 km per year which implies that the function is continuous and has to be provided every year as people will continue to require mobility. In fact, the PB-LCIA should be used for assessing activities where the goal is to assess a function that can be considered to be in continuous demand and, thus, will be continuously provided. This is schematically 
Ryberg MW, Owsianiak M, Richardson K, Hauschild MZ (2018) Development of a life-cycle impact assessment methodology linked to the Planetary Boundaries framework. Ecol Indic 88:250-262. doi: 10.1016/j.ecolind.2017.12.065

shown in Figure 2, where life-cycle stages related to the discrete life-cycles of a continuously fulfilled function are shown. As shown in Figure 2, a conventional LCl includes all elementary flows stemming from a finite set of discrete life-cycles; while the inventory for the PB-LCIA includes the annually occurring elementary flows stemming from overlapping discrete life-cycles which are required for continuously fulfilling the FU.

$\mathrm{LCl}$ modelling for use with PB-LCIA

(inventorying annual elementary flows from all life-cycles

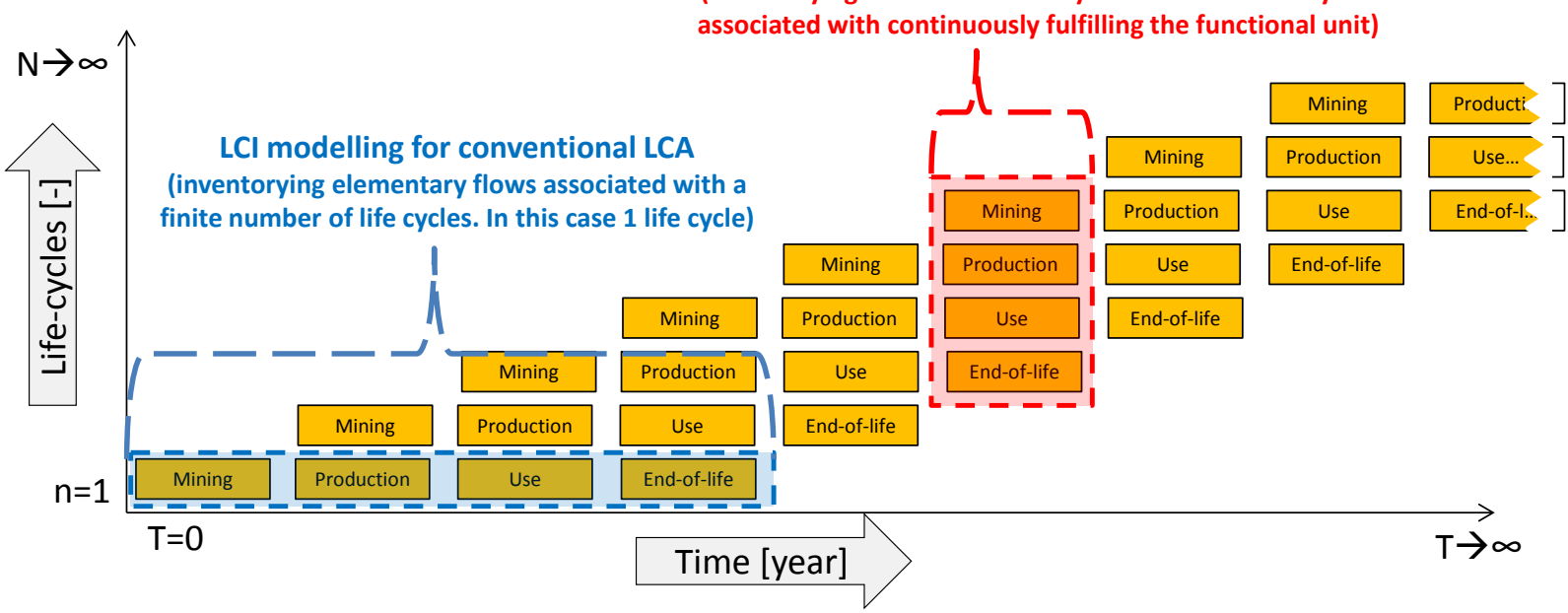

Figure 2. Schematic representation on the difference in derivation and modelling of the LCI using a conventional LCA approach and for an LCA using the PB-LCIA.

Although it is likely that people will demand the same functions today and in the future, it is acknowledged that the way these functions are fulfilled and, thus, environmental profiles, will be very different in the future. For example, there has always been a demand for mobility but economic and technological development has meant that mobility providing functions have developed over time e.g. from horse-riding to cars and airplanes. Such technological changes (e.g. effects of learning, upscaling, change in processes or technologies) are also not commonly considered in traditional LCA but can be assessed using 'what if' analyses. Along the same lines of thinking, and depending on whether an attributional or consequential perspective is applied, the PB-LCIA can be used to indicate either the share of the safe operating space that a particular function occupies (attributional LCA); or the consequential changes in occupation of the safe operating space from a change in how to provide a function in a certain way (e.g. through technological changes).

\subsubsection{Interpretation}

As illustrated by the comparison of results using the PB-LCIA and ILCD-LCIA, conclusions about the best performing product from an LCA using the PB-LCIA are likely to be similar to the ILCD-LCA for the impact 
Ryberg MW, Owsianiak M, Richardson K, Hauschild MZ (2018) Development of a life-cycle impact assessment methodology linked to the Planetary Boundaries framework. Ecol Indic 88:250-262. doi: 10.1016/j.ecolind.2017.12.065

categories which were closely correlated while conclusions may differ for the impact categories with a weaker correlation. This difference in results and thus interpretation can be attributed to the fact that the PB-LCIA and the underlying principles differ from conventional LCA in several aspects where the main differences are presented and discussed in the following section.

Although the primary goal of an assessment using the PB-LCIA is to evaluate the environmental sustainability of an activity, impact scores cannot directly be used for assessing this. Indeed, this requires determination of the share of the safe operating space the activity can be considered entitled, where impact scores of the activity should be within the assigned share of the safe operating space (Ryberg et al. 2016). The safe operating space can be assigned in numerous ways, depending on normative values and perceptions and no standards currently exist for best practice when it comes to assigning a share of the space. Because the safe operating space can be assigned in numerous ways, it is suggested to test how robust any conclusions about an activity's sustainability are to the choice of sharing principle (Ryberg et al. 2016).

A key aspect of the PB-framework is that none of the PBs should be exceeded and transgression of just one PB may lead to an unacceptable risk of a state change in the Earth System due to the interlinkages between the Earth Systems processes. Hence, a 'strong' sustainability perspective (Dobson 1996) should be applied when interpreting results of the PB-LCIA and only activities that do not exceed the assigned safe operating space for any of the PBs can be considered absolutely sustainable. Hence, exceedance of one PB cannot be compensated for by performing well within the assigned space for other PBs. This is in contrast to conventional LCAs, where substitutability between impacts is acceptable and where large impacts within one impact category can be compensated by impact reductions in another impact category (Ryberg et al. 2016).

The CFs for the PB-LCIA in Table 3 primarily express the fate of elementary flows in the environment and exposure of and effect on ecosystems is not part of the CFs. In that sense, the method can be considered relatively immature compared to conventional LCIA methods where exposure and effect on ecosystems is often included through damage modelling. However, further damage modelling of the impact categories in the PB-LCIA e.g., to damage on the Holocene-state would likely be a very difficult endeavor and perhaps not beneficial as this might not adequately represent the complex interactions between the Earth System processes which should be included when trying to estimate the combined effects of impacts on each Earth System process in terms of damage on the Holocene state. Moreover, the PB-LCIA only includes few impact categories relative to conventional LCIAs which is primarily due to a difference in the 'area of protection' 
Ryberg MW, Owsianiak M, Richardson K, Hauschild MZ (2018) Development of a life-cycle impact assessment methodology linked to the Planetary Boundaries framework. Ecol Indic 88:250-262. doi: 10.1016/j.ecolind.2017.12.065

(AoP) for the two approaches. Conventional LCAs are concerned with protecting the three AoPs: human health, biotic natural environment and abiotic natural environment (Jolliet et al. 2004). Thus, impact categories in a conventional LCIA covers all impacts that contribute to any of the AoPs. On the other hand, the PB-framework (and hence the PB-LCIA) focuses on protecting the Earth System from moving out of the Holocene state which is considered a functional value for protecting humanity (Rockström et al. 2009a). Therefore, impact categories are only included for the Earth System components identified in the PBframework. These are substantially fewer than those encompassed by a conventional LCA, mainly because abiotic resources and human health are not included as part of the PB-framework. That they are not included is because they have not been identified as potentially being able in their own right to change the state of the Earth System away from Holocene-like conditions. This also means that an LCA using the PBLCIA will only provide information concerning how the assessed activity contributes or may contribute to occupying the safe operating space, as given from the goal of the study, and will not provide information about an activity's potential impacts on resources and human health. It is important to be aware of these differences and, depending on the goal of the study, it may be beneficial to apply both a conventional LCIA and the PB-LCIA to obtain a comprehensive assessment of how the activity performs relative to the assigned safe operating space identified in the PB-framework and with regards to the conventional AoPs in LCA in order to obtain a more comprehensive basis for decision-making.

By applying the carrying capacity based normalization factors developed by Bjørn and Hauschild (2015), it is already possible to relate impacts scores estimated with ILCD-LCIA to environmental carrying capacities expressed in the default indicators of ILCD-LCIA. However, the added value of using the PB-LCIA compared to e.g. ILCD-LCIA is that PB-LCIA allows for expressing the results in indicators which are consistent with the control variables of the PB-framework. This is a starting point for absolute sustainability assessments using the PB-framework. In fact, this eases communication of LCA results to decision makers already familiar with the PB-concept, thereby, providing a better basis for decision makers to make environmentally conscious and sustainable decisions. Moreover, if a share of the safe operating space is assigned to the activity, then the method can be used for assessing the absolute environmental sustainability of that activity (both production and consumption oriented activities) by evaluating whether or not the activity exceeds its assigned share of the safe operating space and, thus, whether or not it can be considered sustainable in absolute terms. 
Ryberg MW, Owsianiak M, Richardson K, Hauschild MZ (2018) Development of a life-cycle impact assessment methodology linked to the Planetary Boundaries framework. Ecol Indic 88:250-262. doi: 10.1016/j.ecolind.2017.12.065

\subsection{Dealing with overlapping or spatially differentiated boundaries}

For the PB-LCIA, overlapping impact categories were accepted as the overall goal was to comply with the PB-framework and being able to express impacts of activities in metrics of the control variables in the PBframework. The acceptance of overlapping impacts, such as climate change and ocean acidification which both are the result of atmospheric $\mathrm{CO}_{2}$ concentration is not problematic because the PB-LCIA method is not intended for comparisons across impact categories. Instead, the focus is on relating each particular impact category either to the PB or an assigned share of the safe operating space. This differs from conventional LCIA which strives to have mutually exclusive and collectively exhaustive (MECE) impact coverage. This is important because comparisons across impact categories are often done in conventional LCA after normalization and weighting. This may lead to 'double counting' of the same pressures for more than one impact category which may bias results.

Aggregation of the spatially differentiated PBs, i.e. freshwater use, land-system change and atmospheric aerosol loading, to a single score for each impact category was not feasible in the PB-LCIA, as aggregation would require averaging over regions potentially leading to the overlooking of important regional exceedances of the PBs. The reason for this being that control variables of spatially differentiated PBs in the PB-framework are expressed in metrics that are not additive across systems because each depends on the specific spatial system. For instance, for freshwater use at the river basin level; if $50 \%$ and $75 \%$ of the water flow in two river basins is withdrawn for human use, the two shares cannot be added to give the total share of water withdrawn. Instead, the additive values flow volume and withdrawn volume have to be known for each river basin to estimate the average share of water withdrawn for human use across the river basins. This issue was resolved by providing results at different spatial scales; i.e. showing global average results and also spatially differentiated average results to allow assessing impact scores at different spatial resolution. Further improving spatial aggregation would require modification of impact indicators from the PB control variables to additive metrics that are independent of the spatial system. Similar approaches have been used for conventional LCIA methods, where spatially differentiated impact categories are expressed in additive metrics, such as mass equivalents which can be aggregated across spatial systems. The advantage of modifying impact indicators is that regional impacts can be aggregated but the consequence is that a direct link to the PB-framework and the ability to relate impact scores to the safe operating space disappears. 
Ryberg MW, Owsianiak M, Richardson K, Hauschild MZ (2018) Development of a life-cycle impact assessment methodology linked to the Planetary Boundaries framework. Ecol Indic 88:250-262. doi: 10.1016/j.ecolind.2017.12.065

\section{Conclusions}

This work presents the first steps in developing an operational method for quantifying impacts of human activities and expressing these in the metrics of the PB control variables. CFs for a total of 85 elementary flows recognized as dominant contributors to transgressing specific PBs have been calculated. The method can be used for assessing the share of the safe operating space that human activities occupy or for conducting assessments of absolute sustainability after assigning a share of the safe operating space. The current version of the method is considered as a proof-of-concept but further testing and validation is required before the method can be considered mature. Nevertheless, the method can already be used by companies interested in gauging their activities against the PBs, and be used to complement conventional LCAs to aid informed decision making in which the finite nature of Earth's natural capital is taken into account.

\section{Associated content}

Detailed description of characterization methods for each impact category and complementary result figures are provided in the Supporting Info.

\section{Acknowledgements}

The authors acknowledge the valuable feedback from Julie Clavreul, Sarah Sim, and Carina Mueller which helped improving the final manuscript.

\section{References}

Bjørn A, Bey N, Georg S, et al. (2016) Is Earth recognized as a finite system in corporate responsibility reporting? J Clean Prod DOI: 10.1016/j.jclepro.2015.12.095. doi: 10.1016/j.jclepro.2015.12.095

Bjørn A, Diamond M, Owsianiak M, et al. (2015) Strengthening the Link between Life Cycle Assessment and Indicators for Absolute Sustainability To Support Development within Planetary Boundaries. Environ Sci Technol 49:6370-6371. doi: 10.1021/acs.est.5b02106

Bjørn A, Hauschild MZ (2015) Introducing carrying capacity-based normalisation in LCA: framework and development of references at midpoint level. Int J Life Cycle Assess 20:1005-1018. doi: $10.1007 / \mathrm{s} 11367-015-0899-2$

Boucher O, Randall D, Artaxo P, et al. (2013) Clouds and Aerosols. Clim. Chang. 2013 Phys. Sci. Basis. 
Ryberg MW, Owsianiak M, Richardson K, Hauschild MZ (2018) Development of a life-cycle impact assessment methodology linked to the Planetary Boundaries framework. Ecol Indic 88:250-262. doi: 10.1016/j.ecolind.2017.12.065

Contrib. Work. Gr. I to Fifth Assess. Rep. Intergov. Panel Clim. Chang.

Brentrup F, Küsters J, Lammel J, Kuhlmann H (2000) Methods to estimate on-field nitrogen emissions from crop production as an input to LCA studies in the agricultural sector. Int J Life Cycle Assess 5:349-357. doi: 10.1007/BF02978670

Carpenter SR, Bennett EM (2011) Reconsideration of the planetary boundary for phosphorus. Environ Res Lett 6:14009. doi: 10.1088/1748-9326/6/1/014009

Carpenter SR, Caraco NF, Correll DL, et al. (1998) Nonpoint Pollution of Surface Waters with Phosphorus and Nitrogen. Ecol Appl 8:559-568.

Clift R, Sim S, King H, et al. (2017) The Challenges of Applying Planetary Boundaries as a Basis for Strategic Decision-Making in Companies with Global Supply Chains. Sustainability 9:279. doi: $10.3390 /$ su9020279

Cosme N, Koski M, Hauschild MZ (2015) Exposure factors for marine eutrophication impacts assessment based on a mechanistic biological model. Ecol Modell 317:50-63. doi: 10.1016/j.ecolmodel.2015.09.005

Daily GC, Ehrlich PR (1992) Population, Sustainability, and Earth's Carrying Capacity. Bioscience 42:761-771. doi: $10.2307 / 1311995$

Dobson A (1996) Environment sustainabilities: An analysis and a typology. Env Polit 5:401-428. doi: $10.1080 / 09644019608414280$

Doka G (2015) Combining life cycle inventory results with planetary boundaries: The Planetary Boundary Allowance impact assessment method PBA'05. Doka LCA, Zürich

Doka G (2016) Combining life cycle inventory results with planetary boundaries: The Planetary Boundary Allowance impact assessment method Update PBA'06. Doka Life Cycle Assessments, Zurich, Switzerland

Doney SC, Fabry VJ, Feely R a, Kleypas J a (2009) Ocean acidification: the other CO2 problem. Ann Rev Mar Sci 1:169-192. doi: 10.1146/annurev.marine.010908.163834

EC-JRC (2010a) General guide for life cycle assessment-detailed guidance. ILCD Handbook-International Reference Life Cycle Data System, First. JRC, IES. doi: 10.2788/38479 
Ryberg MW, Owsianiak M, Richardson K, Hauschild MZ (2018) Development of a life-cycle impact assessment methodology linked to the Planetary Boundaries framework. Ecol Indic 88:250-262. doi: 10.1016/j.ecolind.2017.12.065

EC-JRC (2011) ILCD Handbook- Recommendations for Life Cycle Impact Assessment in the European context, First. doi: 10.278/33030

EC-JRC (2016) FASST - FAst Scenario Screening Tool. In: Eur. Comm. Jt. Res. Cent. http://tm5fasst.jrc.ec.europa.eu/. Accessed 23 Aug 2016

EC-JRC (2010b) ILCD Handbook: Framework and requirements for LCIA models and indicators. Eur Comm. doi: $10.2788 / 38719$

Fahey DW, Hegglin MI (2011) Twenty Questions and Answers About the Ozone Layer: 2010 Update, Scientific Assessment of Ozone Depletion: 2010. World Meteorological Organization, Geneva, Switzerland

Feely R a, Sabine CL, Lee K, et al. (2004) Impact of anthropogenic CO2 on the CaCO3 system in the oceans. Science 305:362-366.

Feely RA, Orr J, Fabry VJ, et al. (2009a) Present and future changes in seawater chemistry due to ocean acidification. In: Mcpherson BJ, Sundquist ET (eds) Carbon Sequestration Its Role Glob. Carbon Cycle. American Geophysical Union, Washington, D. C., pp 175-188

Feely R, Doney S, Cooley S (2009b) Ocean Acidification: Present Conditions and Future Changes in a HighCO2 World. Oceanography 22:36-47. doi: 10.5670/oceanog.2009.95

Galaz V, Biermann F, Folke C, et al. (2012) Global environmental governance and planetary boundaries: An introduction. Ecol Econ 81:1-3. doi: 10.1016/j.ecolecon.2012.02.023

Gillenwater M, Saarinen K, Ajavon A-LN (2006) Precursors and Indirect Emissions. 2006 IPCC Guidel. Natl. Greenh. Gas Invent. - Vol. 1 Gen. Guid. Report.

Goedkoop M, Heijungs R, Huijbregts MAJ, et al. (2013) ReCiPe 2008 - a life cycle impact assessment method which comprises harmonised category indicators at the midpoint and endpoint level - First Edition. Report 1: Characterisation.

Goodland R (1995) The Concept of Environmental Sustainability. Annu Rev Ecol Syst 26:1-24. doi: 10.1146/annurev.es.26.110195.000245

Guinotte JM, Fabry VJ (2008) Ocean acidification and its potential effects on marine ecosystems. Ann N Y Acad Sci 1134:320-342. doi: 10.1196/annals.1439.013 
Ryberg MW, Owsianiak M, Richardson K, Hauschild MZ (2018) Development of a life-cycle impact assessment methodology linked to the Planetary Boundaries framework. Ecol Indic 88:250-262. doi: 10.1016/j.ecolind.2017.12.065

Hauschild MZ, Goedkoop M, Guinée J, et al. (2013) Identifying best existing practice for characterization modeling in life cycle impact assessment. Int J Life Cycle Assess 18:683-697. doi: 10.1007/s11367-0120489-5

Hauschild MZ, Huijbregts MAJ (2015) Life Cycle Impact Assessment, LCA Compendium-The Complete World of Life Cycle Assessment. doi: 10.1007/978-94-017-9744-3

Heijungs R (1995) Harmonization of methods for impact assessment. Environ Sci Pollut Res 2:217-224. doi: 10.1007/BF02986769

Hoekstra AY, Mekonnen MM (2011) Global water scarcity: monthly blue water footprint compared to blue water availability for the world's major river basins. Value of Water Research Report Series No. 53, UNESCO-IHE, Delft, the Netherlands

Howarth RW, Marino R (2006) Nitrogen as the limiting nutrient for eutrophication in coastal marine ecosystems: Evolving views over three decades. Limnol Oceanogr 51:364-376. doi: 10.4319/lo.2006.51.1_part_2.0364

Huijbregts MAJ, Hellweg S, Hertwich E (2011) Do We Need a Paradigm Shift in Life Cycle Impact Assessment? 3833-3834. doi: 201110.1002/ieam.141.(5)

ISO (2006a) ISO 14040: Environmental management - Life cycle assessment - Principles and framework.

ISO (2006b) ISO 14044: Environmental management-Life cycle assessment-Requirements and guidelines. International Organization for Standardization

Jolliet O, Müller-Wenk R, Bare J, et al. (2004) The LCIA midpoint-damage framework of the UNEP/SETAC life cycle initiative. Int J Life Cycle Assess 9:394-404. doi: 10.1007/BF02979083

Langevin B, Basset-Mens C, Lardon L (2010) Inclusion of the variability of diffuse pollutions in LCA for agriculture: the case of slurry application techniques. J Clean Prod 18:747-755. doi: 10.1016/j.jclepro.2009.12.015

Laurent A, Olsen SI, Hauschild MZ (2012) Limitations of carbon footprint as indicator of environmental sustainability. Environ Sci Technol 46:4100-8. doi: 10.1021/es204163f

Laurent A, Owsianiak M (2017) Potentials and limitations of footprints for gauging environmental sustainability. Curr Opin Environ Sustain 25:20-27. doi: 10.1016/j.cosust.2017.04.003 
Ryberg MW, Owsianiak M, Richardson K, Hauschild MZ (2018) Development of a life-cycle impact assessment methodology linked to the Planetary Boundaries framework. Ecol Indic 88:250-262. doi: 10.1016/j.ecolind.2017.12.065

Levasseur A, Cavalett O, Fuglestvedt JS, et al. (2016) Enhancing life cycle impact assessment from climate science: Review of recent findings and recommendations for application to LCA. Ecol Indic 71:163174. doi: 10.1016/j.ecolind.2016.06.049

Meinshausen M, Smith SJ, Calvin K, et al. (2011) The RCP greenhouse gas concentrations and their extensions from 1765 to 2300. Clim Change 109:213-241. doi: 10.1007/s10584-011-0156-z

Myhre G, Highwood EJ, Shine KP, Stordal F (1998) New estimates of radiative forcing due to well mixed greenhouse gases. Geophys Res Lett 25:2715. doi: 10.1029/98GL01908

Myhre G, Shindell D, Bréon F-M, et al. (2013) Anthropogenic and Natural Radiative Forcing. In: Stocker TF, Qin D, Plattner G-K, et al. (eds) Clim. Chang. 2013 Phys. Sci. Basis. Contrib. Work. Gr. I to Fifth Assess. Rep. Intergov. Panel Clim. Chang. Cambridge University Press, Cambridge, United Kingdom and New York, NY, USA, pp 659-740

Orr JC, Fabry VJ, Aumont O, et al. (2005) Anthropogenic ocean acidification over the twenty-first century and its impact on calcifying organisms. Nature 437:681-686. doi: 10.1038/nature04095

Pastor A V., Ludwig F, Biemans H, et al. (2014) Accounting for environmental flow requirements in global water assessments. Hydrol Earth Syst Sci 10:14987-15032. doi: 10.5194/hessd-10-14987-2013

Poff NL, Richter BD, Arthington AH, et al. (2010) The ecological limits of hydrologic alteration (ELOHA): A new framework for developing regional environmental flow standards. Freshw Biol 55:147-170. doi: 10.1111/j.1365-2427.2009.02204.x

Ramanathan V, Chung C, Kim D, et al. (2005) Atmospheric brown clouds: impacts on South Asian climate and hydrological cycle. Proc Natl Acad Sci U S A 102:5326-5333. doi: 10.1073/pnas.0500656102

Ramanathan V, Crutzen PJ, Kiehl JT, Rosenfeld D (2001) Aerosols, Climate, and the Hydrological Cycle. Science 1:2119-2124.

Rockström J, Steffen W, Noone K, et al. (2009a) Planetary boundaries: Exploring the safe operating space for humanity. Ecol Soc 14:32.

Rockström J, Steffen W, Noone K, et al. (2009b) A safe operating space for humanity. Nature 461:472-5. doi: $10.1038 / 461472 a$

Ryberg MW, Owsianiak M, Richardson K, Hauschild MZ (2016) Challenges in implementing a Planetary 
Ryberg MW, Owsianiak M, Richardson K, Hauschild MZ (2018) Development of a life-cycle impact assessment methodology linked to the Planetary Boundaries framework. Ecol Indic 88:250-262. doi: 10.1016/j.ecolind.2017.12.065

Boundaries based Life-Cycle Impact Assessment Methodology. J Clean Prod 139:450-459. doi: 10.1016/j.jclepro.2016.08.074

Sandin G, Peters GM, Svanström M (2015) Using the planetary boundaries framework for setting impactreduction targets in LCA contexts. Int J Life Cycle Assess 20:1684-1700. doi: 10.1007/s11367-0150984-6

Scheffer M, Carpenter S, Foley JA, et al. (2001) Catastrophic shifts in ecosystems. Nature 413:591-596. doi: $10.1038 / 35098000$

Schindler DW (1977) Evolution of phosphorus limitation in lakes. Science 195:260-262. doi: $10.1126 /$ science.195.4275.260

Shine KP, Fuglestvedt JS, Hailemariam K, Stuber N (2005) Alternatives to the Global Warming Potential for comparing climate impacts of emissions of greenhouse gases. Clim Change 68:281-302. doi: $10.1007 / \mathrm{s} 10584-005-1146-9$

Sim S, King H, Price E (2016) The Role of Science in Shaping Sustainable Business : Unilever Case Study. In: Clift R, Druckman A (eds) Tak. Stock Ind. Ecol. Springer International Publishing, Heidelberg, New York, Dordrecht, London, pp 291-302

Smakhtin V (2008) Basin Closure and Environmental Flow Requirements. Int J Water Resour Dev 24:227233. doi: $10.1080 / 07900620701723729$

Smith V (2003) Eutrophication of freshwater and coastal marine ecosystems a global problem. Environ Sci Pollut Res 10:126-139. doi: 10.1065/espr2002.12.142

Steffen W, Richardson K, Rockström J, et al. (2015) Planetary boundaries: Guiding human development on a changing planet. Science 347:1217. doi: 10.1126/science.1259855

Stockholm Resilience Centre (2015) New partnership - Bridging the business-science gap. In: New Partnersh. - Bridg. business-science gap. http://www.stockholmresilience.org/research/researchnews/2012-09-08-bridging-the-business-science-gap.html. Accessed 25 Jun 2016

Tuomisto HL, Hodge ID, Riordan P, MacDonald DW (2012) Exploring a safe operating approach to weighting in life cycle impact assessment - A case study of organic, conventional and integrated farming systems. J Clean Prod 37:147-153. doi: 10.1016/j.jclepro.2012.06.025 
Ryberg MW, Owsianiak M, Richardson K, Hauschild MZ (2018) Development of a life-cycle impact assessment methodology linked to the Planetary Boundaries framework. Ecol Indic 88:250-262. doi: 10.1016/j.ecolind.2017.12.065

UN (2015) Transforming our world: The 2030 agenda for sustainable development. United Nations, New York

UNEP (1997) World atlas of desertification, 2nd ed. United Nations Environment Programme, London Vadas PA (2013) Annual Phosphorus Loss Estimator - User's Manual Version 2.4. U.S. Dairy Forage Research Center, Agricultural Research Service, United States Department of Agriculture, Madison, Wisconsin, USA

Vadas PA, Good LW, Moore PA, Widman N (2009) Estimating Phosphorus Loss in Runoff from Manure and Fertilizer for a Phosphorus Loss Quantification Tool. J Environ Qual 38:1645. doi: 10.2134/jeq2008.0337

Vadas PA, Joern BC, Moore PA (2012) Simulating Soil Phosphorus Dynamics for a Phosphorus Loss Quantification Tool. J Environ Qual 0:0. doi: 10.2134/jeq2012.0003

Vitousek PM (1997) Human Domination of Earth's Ecosystems. Science 277:494-499. doi: 10.1126/science.277.5325.494

Vitousek PM, Hättenschwiler S, Olander L, Allison S (2002) Nitrogen and Nature. AMBIO A J Hum Environ 31:97-101. doi: 10.1579/0044-7447-31.2.97

De Vries W, Kros J, Kroeze C, Seitzinger SP (2013) Assessing planetary and regional nitrogen boundaries related to food security and adverse environmental impacts. Curr Opin Environ Sustain 5:392-402. doi: 10.1016/j.cosust.2013.07.004

van Vuuren DP, Stehfest E, den Elzen MGJ, et al. (2011) RCP2.6: exploring the possibility to keep global mean temperature increase below $2^{\circ} \mathrm{C}$. Clim Change 109:95-116. doi: 10.1007/s10584-011-0152-3

Wanninkhof R, Asher WE, Ho DT, et al. (2009) Advances in quantifying air-sea gas exchange and environmental forcing. Ann Rev Mar Sci 1:213-244. doi: 10.1146/annurev.marine.010908.163742

Weidema BP, Bauer C, Hischier R, et al. (2013) The ecoinvent database: Overview and methodology, Data quality guideline for the ecoinvent database version 3.

Wenzel H, Hauschild MZ (1998) Environmental Assessment of Products: Volume 2: Scientific Background. Chapman \& Hall, London

Yu H, Chin M, West JJ, et al. (2013) A multimodel assessment of the influence of regional anthropogenic 
Ryberg MW, Owsianiak M, Richardson K, Hauschild MZ (2018) Development of a life-cycle impact assessment methodology linked to the Planetary Boundaries framework. Ecol Indic 88:250-262. doi: 10.1016/j.ecolind.2017.12.065

emission reductions on aerosol direct radiative forcing and the role of intercontinental transport. J Geophys Res Atmos 118:700-720. doi: 10.1029/2012JD018148

van Zelm R, Preiss P, van Goethem T, et al. (2016) Regionalized life cycle impact assessment of air pollution on the global scale: Damage to human health and vegetation. Atmos Environ 134:129-137. doi: 10.1016/j.atmosenv.2016.03.044 